\title{
The Quest for a Sound Conception of Copyright's Derivative Work Right
}

\begin{abstract}
Pamela Samuelson*

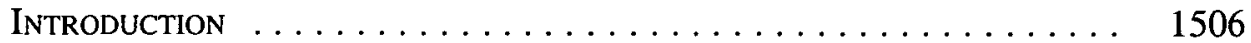

I. The Origins and Evolution of the Derivative Work Right . . . 1511

II. The Derivative Work Right Covers the Nine Examples and Close Analogues . . . . . . . . . . . . . . . . . . 1517

A. CHARACTERISTICS OF THE NINE EXEMPLARY DERIVATIVES $\ldots \ldots .1518$

1. Shorter Versions . . . . . . . . . . . . . . . 1518

2. Faithful Renditions . . . . . . . . . . . . . . . 1519

3. Transformations of Expression from One Medium or Genre to Another . . . . . . . . . . . . . . 1520

B. CLOSE ANALOGUES TO THE NINE EXAMPLES ARE DERIVATIVE WORKS $\ldots \ldots \ldots \ldots \ldots \ldots \ldots \ldots \ldots \ldots \ldots \ldots \ldots \ldots \ldots \ldots \ldots$

C. CONSTRUING THE DERIVATIVE RIGHT IN LIGHT OF THE DEFINITIONAL EXAMPLES $\ldots \ldots \ldots \ldots \ldots \ldots$

III. Three Justifications for the Grant of Derivative WORK RIGHTS $\ldots \ldots \ldots \ldots \ldots \ldots \ldots \ldots \ldots \ldots \ldots \ldots \ldots \ldots \ldots$

A. DERIVATIVE WORK RIGHTS ARE IMPORTANT TO INVESTMENTS FOR SOME CREATORS . . . . . . . . . . . . . . . . . . 1528

B. AUTHORS SHOULD HAVE TIME TO PLAN DERIVATIVES . . . . . . . 1530

C. UNJUST ENRICHMENT CONSIDERATIONS . . . . . . . . . . 1532

IV. Derivative Uses that Are Not Within the Derivative

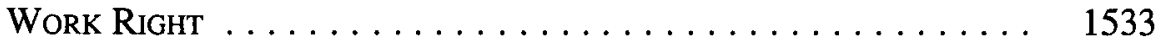

A. USEFUL ARTICLES ARE NOT DERIVATIVE WORKS . . . . . . . . 1534

* Richard M. Sherman Distinguished Professor of Law and Information, University of California, Berkeley. (O) 2013, Pamela Samuelson. I wish to thank Micah Gruber, Andrea Yankovsky, Ana Enriquez, and Kathryn Hashimoto for invaluable research assistance. I am grateful for thoughtful feedback on earlier drafts from Michael Abramowicz, Barton Beebe, Maggie Chon, Brett Frischmann, Paul Geller, Mark Gergen, Daniel Gervais, Jane Ginsburg, Kathryn Hashimoto, Mark Lemley, Lydia Loren, Tyler Ochoa, Tony Reese, Molly Van Houweling, Steve Wilf, and Diane Zimmerman as well as from colleagues from Berkeley, Columbia, Fordham, N.Y.U., and the Universities of Connecticut and Virginia Law Schools, where I workshopped earlier versions of this Article. 
B. SOME DERIVATIVE USES ARE PRIVILEGED $\ldots \ldots \ldots \ldots \ldots \ldots$

C. SUPPLEMENTARY WORKS ARE NOT DERIVATIVE WORKS $\ldots \ldots \ldots$

D. CONCORDANCES AND SIMILAR REFERENCE WORKS ARE NOT DERIVATIVE WORKS $\ldots \ldots \ldots \ldots \ldots \ldots \ldots \ldots$

E. INTEROPERABLE AND ADD-ON SOFTWARE ARE NOT DERIVATIVE

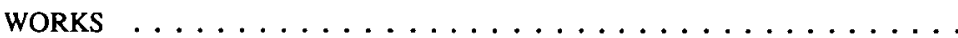

F. VARIOUS ONLINE ACTIVITIES DO NOT CREATE DERIVATIVE WORKS .

G. SUMMING UP: WHAT ARE AND ARE NOT DERIVATIVE WORKS $\ldots \ldots$

V. Problematic Derivative Work Cases $\ldots \ldots \ldots \ldots \ldots \ldots$

A. SHOULD COMPLEMENTARY WORKS INFRINGE THE DERIVATIVE WORK RIGHT? . . . . . . . . . . . . . . .

B. DOES TINKERING WITH PURCHASED COPIES INFRINGE THE DERIVATIVE WORK RIGHT? . . . . . . . . . . . .

C. WHEN SHOULD ARTISTIC TRANSFORMATIONS BE FAIR USES? $\ldots \ldots$

D. SHOULD THE DERIVATIVE WORK RIGHT EXTEND TO DERIVATIVE USES IN REMOTE AND UNFORESEEN MARKETS? . . . . . . . . .

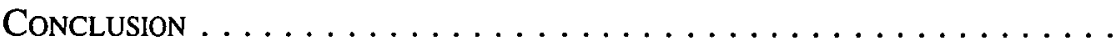

\section{INTRODUCTION}

For more than two hundred years after the English Parliament enacted the first modern copyright law, ${ }^{1}$ authors in England and the United States had no statutory right to control the making or exploitation of derivatives of their works. ${ }^{2}$ It was considered fair practice, for example, to translate an author's work from one language to another, ${ }^{3}$ to abridge an existing work as long as the

1. Statute of Anne, 8 Ann., c. 19 (1710) (Eng.). I have elsewhere argued this statute was the first modern copyright law because in contrast to the Stationers' private copyright regime, it contained the basic elements associated with copyright law: a grant of certain exclusive rights to authors of original books for limited times in order to promote learning. See Pamela Samuelson, Copyright and Freedom of Expression in Historical Perspective, 10 J. INTELL. PROP. L. 319, 324-25 (2003).

2. The earliest harbinger of today's derivative work right was an exclusive right the U.S. Congress granted in 1802 to makers of prints forbidding copying "in whole or in part, by varying, adding to, or diminishing from the main design." See David Rabinowitz, Everything You Ever Wanted To Know About the Copyright Act Before 1909, but Couldn't Be Bothered To Look Up, 49 J. CopYriGHT Soc'Y USA 649, 652-53 (2001) (quoting the statutory language).

3. See, e.g., Stowe v. Thomas, 23 F. Cas. 201, 208 (C.C.E.D. Pa. 1853) (No. 13,514) (holding that an unauthorized translation of Uncle Tom's Cabin from English to German was noninfringing); Burnett v. Chetwood, (1721) 35 Eng. Rep. 1008 (Ch.) 1009; 2 Mer. 441, 442 (holding that an English translation of a Latin work did not infringe). An early commentator criticized English law for having failed to grant authors rights to control translations. See Augustine Birrell, Seven Lectures on the Law and History OF COPYRIGHT IN BOOKS 154-55 (1899). Dramatizations of novels apparently were also 
abridgement was itself creatively done, ${ }^{4}$ and to reproduce substantial parts of another's work as long as the second comer made improvements. ${ }^{5}$ This was not because judges took a literalist approach to copyright infringement (that is, regarding only exact or near-exact copying as infringement), but rather because the judges perceived translations, abridgements, and improvements as intellectual products of the second comers' creativity and because new works that built on preexisting works contributed to the advancement of knowledge-the very goal of modern copyright law. ${ }^{6}$

The copyright goal of advancing knowledge has constitutional roots in the U.S. tradition. The part of the Constitution that authorizes Congress to enact copyright legislation is explicit that the purpose of the grant is "[t]o promote the Progress of Science" (by which the founders meant knowledge). ${ }^{7}$ This goal was particularly important when the Constitution was formed because the founders believed that an educated populace would be necessary to sustain the democratic republic they had founded. ${ }^{8}$ The Supreme Court has repeatedly recognized that " $[t]$ he sole interest of the United States and the primary object in conferring the [copyright] monopoly lie in the general benefits derived by the public from the labors of authors." "9 The means by which the founders expected the constitutional purpose to be achieved was through a limited grant of rights to authors that would induce them to invest in creative work so that they could,

considered noninfringing in much of the nineteenth century. See id. at 155-56. On rare occasions, adaptations were found infringing. See D'Almaine v. Boosey, (1835) 160 Eng. Rep. 117 (K.B.) 123; 1 Y. \& C. Ex. 288, 302-03 (holding an adaptation of opera music to be infringing).

4. See, e.g., Gyles v. Wilcox, (1740) 26 Eng. Rep. 489 (Ch.) 490; 2 Atk. 141, 143 ('“A]bridgments may with great propriety be called a new book, because . . . the invention, learning, and judgment of the author is [shown] in them ...."); Hawkesworth v. Newberry, (1774) Lofft 775 (holding that an abridgement of Dr. Hawkesworth's Voyages was a fair abridgement). An early treatise approved of this rule. See Robert Maugham, A Treatise on the Laws of Literary Property 129-30 (1828). Although historical evidence supports the view that the Statute of Anne did not cover abridgements, sometimes printers obtained privileges that were broad enough to cover abridgements. See Ronan Deazley, The Statute of Anne and the Great Abridgement Swindle, 47 Hous. L. Rev. 793, 810-11 (2010).

5. See, e.g., Matthewson v. Stockdale, (1806) 33 Eng. Rep. 103 (Ch.) 105; 12 Ves. Jun. 270, 275 (noting that an improvement on an original is noninfringing); Sayre v. Moore, (1785) (holding that the reuse of elements of a navigation map was noninfringing because of defendant's improvements), cited in Cary v. Longman, (1801) 120 Eng. Rep. 138 (K.B.) 139 n.b; 1 East 358, 361 n.b. The Maugham treatise also approved of this rule. MAUGHaM, supra note 4, at 162-64.

6. U.S. Const. art. I, $\$ 8, \mathrm{cl} .8$ (giving Congress the power to enact legislation to grant exclusive rights to authors in order "[t]o promote the Progress of Science"); Statute of Anne, 8 Ann., c. 19 (1710) (Eng.) ("An Act for the Encouragement of Learning ....").

7. U.S. Const. art. I, $\$ 8$, cl. 8; see, e.g., Edward C. Walterscheid, The Nature of the Intellectual Property Clause: A Study in Historical Perspective 125-26 (2002) (explaining that the founders used the word "science" in this clause to mean "knowledge").

8. See, e.g., Dotan Oliar, Making Sense of the Intellectual Property Clause: Promotion of Progress as a Limitation on Congress's Intellectual Property Power, 94 GEo. L.J. 1771, 1808-16 (2006); L. Ray Patterson \& Craig Joyce, Copyright in 1791: An Essay Concerning the Founders' View of the Copyright Power Granted to Congress in Article I, Section 8, Clause 8 of the U.S. Constitution, 52 EMORY L.J. 909,929 \& n.46 (2003).

9. Sony Corp. of Am. v. Universal City Studios, Inc., 464 U.S. 417, 429 (1984) (quoting Fox Film Corp. v. Doyal, 286 U.S. 123, 127 (1932)). 
if they wished, control certain commercial exploitations of their works. ${ }^{10}$ Yet, in order for science to progress, it has long been thought necessary to limit the rights of first-generation creators, partly through internal limits to exclusive rights and partly through doctrines such as fair use, so that there would be ample breathing room for follow-on creators to express themselves and make works that would compete fairly with preexisting works. ${ }^{11}$ Follow-on creation is also fostered by judicial recognition that "in literature, in science and in art, there are, and can be, few, if any, things, which in an abstract sense, are strictly new and original throughout. Every book in literature, science and art, borrows, and must necessarily borrow, and use much which was well known and used before." 12

The constitutionally protected interests of the public are not exhausted merely by the availability of products and services in the marketplace that may be offered by copyright owners. Also within the purview of the constitutional purpose of U.S. copyright law are the public's interests in reading, listening to, and viewing the diverse works of authorship that copyright law protects, in making noninfringing uses of them, and in enjoying the fruits of technological progress. ${ }^{13}$ In keeping with these considerations, the Court has opined that "“[w]hen technological change has rendered its literal terms ambiguous, the Copyright Act must be construed in light of this basic [constitutional] purpose." $" 14$

Copyright law fulfills its constitutional mandate through a careful and conscientious balancing of the rights granted to authors with the public interest. Although courts initially viewed derivatives favorably because of the second comer's creativity, by the mid- to late-nineteenth century, courts and legislatures began to be more receptive to claims that specific types of derivative works should be within authorial control. In 1841, for instance, Justice Story ruled that an unauthorized abridgement of an eleven-volume compilation of George Washington's letters was not a fair abridgement, ${ }^{15}$ and in 1870 , Congress amended

10. See U.S. ConST. art. I, $\S 8$, cl. 8 ; Sony, 464 U.S. at 429 . For almost 200 years, authors had to opt-in to the copyright regime by complying with formalities such as putting notices on published copies of their works and registering their copyright claims. See, e.g., Christopher Sprigman, Reform(aliz)ing Copyright, 57 StAN. L. REv. 485, 487 (2004).

11. See, e.g., Campbell v. Acuff-Rose Music, Inc., 510 U.S. 569, 579 (1994) ("[T] he goal of copyright, to promote science and the arts, is generally furthered by the creation of transformative works. Such works thus lie at the heart of the fair use doctrine's guarantee of breathing space within the confines of copyright ....”).

12. Id. at 575 (quoting Emerson v. Davies, 8 F. Cas. 615, 619 (C.C.D. Mass. 1845) (No. 4436)).

13. Campbell, 510 U.S. at 578 n.10 (mentioning the public interest in access to new works, even in those that might have transgressed copyright's limits); Sony, 464 U.S. at $440-42$ (recognizing the public interest in having access to technologies that allow them to engage in noninfringing uses of copyrighted works, such as making time-shift copies of television programs); see also Jessica Litman, Readers ' Copyright, 58 J. CopYRIGHr Soc'y USA 325, 330-31 (2011) (discussing reader interests in copyright).

14. Sony, 464 U.S. at 432 (quoting Twentieth Century Music Corp. v. Aiken, 422 U.S. 151, 156 (1975)).

15. See Folsom v. Marsh, 9 F. Cas. 342, 349 (C.C.D. Mass. 1841) (No. 4901) (holding that an abridgment of volumes of George Washington's letters infringed copyright). 
U.S. copyright law to grant authors the right to control translations and dramatizations of their works. ${ }^{16}$ In 1909, Congress provided a more expansive but still specific list of derivatives that authors were entitled to control. ${ }^{17}$ Not until the Copyright Act of 1976 (1976 Act) did U.S. law grant authors a general right to control the preparation of derivative works. ${ }^{18}$ This Act defined a "derivative work" as "a work based upon one or more preexisting works, such as a translation, musical arrangement, dramatization, fictionalization, motion picture version, sound recording, art reproduction, abridgement, condensation, or any other form in which a work may be recast, transformed, or adapted." 19

The derivative work right has proven unproblematic and uncontroversial in cases involving the nine exemplary derivatives and close analogues, ${ }^{20}$ but it has been highly problematic in some cases in which courts have interpreted broadly the clause with which the definition ends ("or any other form in which the work is recast, transformed, or adapted"). ${ }^{21}$ Some courts and commentators have interpreted this clause as giving copyright owners an entitlement to control all markets into which any emanation of their works might travel. ${ }^{22}$ Some have speculated that even noncommercial derivatives, such as amateur remixes and

16. Copyright Act, ch. 230, § 86, 16 Stat. 198, 212 (1870) (repealed 1909). This amendment was actually more modest than the textual statement implies. The $1870 \mathrm{Act}$ allowed authors to reserve the right to control translations and dramatizations; in the absence of a reservation, others could still translate or dramatize works without permission. Id. Daniel Gervais has pointed out that many nations in the nineteenth and early twentieth centuries limited the power of authors to control translations of their works (for example, the right would terminate if an authorized translation was not made within ten years of the work's first publication). See Daniel Gervais, The Derivative Right, or Why Copyright Law Protects Foxes Better than Hedgehogs, 15 VAND. J. ENT. \& TECH. L. 785, 811-12 (2013).

17. Copyright Act of 1909, Pub. L. No. $60-349$, § 1(b), 35 Stat. 1075, 1075, repealed by Copyright Act of 1976, Pub. L. No. 94-553, 90 Stat. 2541 (codified as amended at 17 U.S.C. $\$ \S 101-810$, 18 U.S.C. $\$ 2318,44$ U.S.C. $\$ \S 505,2113(2006))$.

18. 17 U.S.C. $\S 106(2)$. As Part I explains, the United States was the first country in the world to adopt a derivative work right as such. The English adaptation right is defined in terms of specific types of derivative uses that authors are entitled to control. See Copyright, Designs and Patents Act, 1988, c. 48, § 21 (Eng.), available at http://www.legislation.gov.uk/ukpga/1988/48/section/21.

19. 17 U.S.C. $\$ 101$.

20. See, e.g., Zomba Enters., Inc. v. Panorama Records, Inc., 491 F.3d 574, 574-75 (6th Cir. 2007) (holding that unauthorized sound recordings of music for karaoke were infringing); Mulcahy v. Cheetah Learning LLC, 386 F.3d 849, 854-55 (8th Cir. 2004) (reversing summary judgment and remanding for analysis of a derivative work claim in a case involving condensation of test materials); Radji v. Khakbaz, 607 F. Supp. 1296, 1303 (D.D.C. 1985) (holding that an unauthorized translation of substantial excerpts from plaintiff's book infringed the derivative work right).

21. See infra Part V.

22. Professor Chafee was an early advocate of a broad right to control derivatives. See Zechariah Chafee, Jr., Reflections on the Law of Copyright: I, 45 CoLum. L. Rev. 503, 505 (1945) ("The essential principle is the author's right to control all the channels through which his work or any fragments of his work reach the market."). This principle was most fully realized in Castle Rock Entertainment, Inc. v. Carol Publishing Group, Inc., 150 F.3d 132, 140 (2d Cir. 1998) (holding that a trivia game based upon television programs infringed copyright), discussed infra notes 290-300 and accompanying text. Even Chafee, however, thought that there should be some limits on the scope of this right. Chafee, supra, at 506-07. The modern scholar who has the most expansive view of the derivative work right is Paul Goldstein. See Paul Goldstein, Goldstein on Copyright $\$ 5.3 .1$ (3d ed. 2005). 
mashups, might infringe this right. ${ }^{23}$ Most commentators have decried the overbreadth of the derivative work right and offered suggestions about how it might be narrowed. ${ }^{24}$ Although one prominent treatise author considers the derivative work right to be superfluous, ${ }^{25}$ another thinks that the derivative work right has replaced fair use as the "most troublesome" doctrine of U.S. copyright law. ${ }^{26}$ Mysteries abound about the proper scope of the derivative work right. ${ }^{27}$

23. This claim is plausible because 17 U.S.C. $\$ 106(2)$ gives authors the right not just to exploit derivative works but also to prepare them. The substantial literature on user-generated content, such as remixes and mashups, expresses concern that noncommercial remixes might infringe the derivative work right, although these commentators generally argue that noncommercial remixes should be deemed noninfringing through fair use or other doctrines. See, e.g., Anupam Chander \& Madhavi Sunder, Everyone's a Superhero: A Cultural Theory of "Mary Sue" Fan Fiction as Fair Use, 95 CALIF. L. Rev. 597, 600 (2007); Molly Shaffer Van Houweling, Distributive Values in Copyright, 83 Tex. L. REv. 1535, 1538-39 (2005). The rarity of litigation making derivative work claims against usergenerated content is notable and suggests that these works do not infringe. See, e.g., Edward Lee, Warming Up to User-Generated Content, 2008 U. ILL. L. Rev. 1459, 1479-81. Despite the statutory language, mere preparation of a derivative work does not generally give rise to copyright liability. Courts tend to focus on the work disseminated to the public. See, e.g., Davis v. United Artists, Inc., 547 F. Supp. 722, 724 n.9 (S.D.N.Y. 1982). But see Anderson v. Stallone, 11 U.S.P.Q.2d (BNA) 1161, 1165 (C.D. Cal. 1989) (holding that an outline for a sequel to the Rocky movies infringed the derivative work right).

24. See, e.g., Christina Bohannan, Taming the Derivative Works Right: A Modest Proposal for Reducing Overbreadth and Vagueness in Copyright, 12 VAND. J. ENT. \& TECH. L. 669, 692-94 (2010) (proposing First Amendment limits on the derivative work right); Glynn S. Lunney, Jr., Reexamining Copyright's Incentives-Access Paradigm, 49 VAND. L. Rev. 483, 650-53 (1996) (making an economic argument for a narrow derivative work right); Neil Weinstock Netanel, Copyright and a Democratic Civil Society, 106 YALE L.J. 283, 347-64 (1996) (arguing that the derivative work right should not give authors control over transformative uses that would enhance expressive pluralism and diversity); Christopher M. Newman, Transformation in Property and Copyright, 56 ViLL. L. Rev. 251, 298-304 (2011) (drawing upon property-law concepts to narrow the derivative work right); Tyler T. Ochoa, Copyright, Derivative Works and Fixation: Is Galoob a Mirage, or Does the Form(Gen) of the Alleged Derivative Work Matter?, 20 SANTA ClaRA COMPUTER \& High TeCh. L.J. 991, 1020 (2004) (proposing to narrow the derivative work right by tying it to other exclusive-rights violations); Stewart E. Sterk, Rhetoric and Reality in Copyright Law, 94 MicH. L. Rev. 1197, 1215-17 (1996) (arguing that greater weight should be given to second comers' creativity in derivative work cases); Naomi Abe Voegtli, Rethinking Derivative Rights, 63 BROOK. L. Rev. 1213, 1267 (1997) (proposing a narrower formulation of the derivative work right); Tim Wu, Tolerated Uses, 31 CoLUM. J.L. \& ARTs 617, 631 (2008) (arguing that complementary works should be deemed noninfringing).

25. Melville B. Nimmer \& David Nimmer, Nimmer on Copyright \& 8.09 [A] (2012). The seeming superfluity of the derivative work right arises from the fact that this treatise regards this right as not being infringed unless a defendant has taken enough expression from the first work to be an infringing reproduction or unless the defendant has publicly performed expression from the underlying work so that the public-performance right has been infringed. The only possible role for the derivative work right alone is, in its view, when an author has licensed a second party to reproduce her work but not to make derivatives. Id.

26. Wrulam F. Patry, Patry on Copyright $\$ 3: 46$ (2013). Patry goes on to say that "regrettably the understanding of derivative works is fast approaching incomprehensibility." $I d$.

27. Part $\mathrm{V}$ addresses several of these mysteries. This Article does not address other vexing derivative work issues, such as the degree of originality that a derivative work must exhibit as compared with the underlying work to be separately copyrightable. See, e.g., Gracen v. Bradford Exch., 698 F.2d 300, 305 (7th Cir. 1983) (requiring substantial originality for separate copyright in derivative work). Nor does it consider the distinction between a copy and a derivative work in connection with restoration of 
Part I of this Article explains that, viewed in light of the evolution of the derivative work concept in the copyright revision process, the exclusive right to prepare derivative works is narrower in scope and more bounded than commentators have often feared. Part II considers characteristics of the nine exemplary derivatives in the statutory definition and explains why they should inform a sound interpretation of the last clause in the definition. By including these nine examples, Congress intended to provide guidance about the types of derivatives covered by this right. To be consistent with the text of the statute, the legislative history, and the constitutional purpose of copyright, derivative work liability should only be imposed under the last clause of the definition if the plaintiff's claim is analogous to one or more of the exemplary derivatives in the statutory definition. Part III discusses three plausible justifications for the grant of the derivative work right that, properly understood, constrain its reach. Part IV considers several provisions and doctrines of U.S. copyright law that further limit the reach of the derivative work right. The statutory exclusion of useful articles from the scope of copyright protection, for instance, meaningfully limits the derivative work right in a manner consistent with the constitutional purpose of copyright law and policies favoring ongoing innovation and competition. Fair use protects free-expression interests of next-generation authors, along with the first-sale limit, which protects privacy and autonomy interests of those who have purchased copies of copyrighted works. Part V discusses a handful of derivative-use cases that have given overbroad interpretations to the derivative work right and explains why these decisions are unsound.

\section{The Origins and Evolution of the Derivative Work Right}

The exclusive-rights provision of the Copyright Act of 1909 (1909 Act) was both lengthy and complicated. ${ }^{28}$ An important objective of the copyright revision effort was to simplify and clarify the law's exclusive-rights provisions. ${ }^{29}$ Particularly in need of revision was the way that the 1909 Act handled translations and other adaptations. The 1909 Act granted authors of literary works an exclusive right to control translations of their works; authors of nondramatic works had the right to convert them into dramatic works; authors of dramatic works had the right to convert them into novels or other nondramatic works; authors of musical works had rights to arrange or adapt the music; artist-authors

copyrights under 17 U.S.C. $§ 104$ A. See, e.g., Dam Things from Den. v. Russ Berrie \& Co., 290 F.3d 548, 563 (3d Cir. 2002).

28. Copyright Act of 1909, Pub. L. No. 60-349, § 1, 35 Stat. 1075, 1075 (repealed 1976). It was more than 1000 words long with five subsections, each of which granted several specific types of exclusive rights. Id. The 1976 Act exclusive-rights provision was 133 words. 17 U.S.C. $\S 106$ (2006).

29. See, e.g., House Comm. on the Judiciary, 89th Cong., Copyright law Revision Part 6:

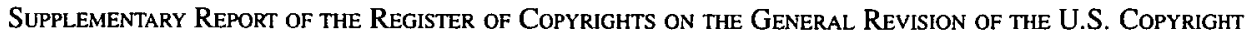
Law: 1965 Revision Bill 15 (Comm. Print 1965); House Comm. on the Judiciary, 87th Cong., Copyright Law Revision: Report of the Register of Copyrights on the General Revision of the U.S. COPYRIGHT LaW 24 (Comm. Print 1961). 
were given the right to complete, execute, and finish models or designs for works of art. ${ }^{30}$ The 1909 Act not only identified specific types of derivatives that authors were entitled to control; it also tied each type of derivative to the type of work being adapted.

When the Register of Copyrights issued his first report on proposed revision to U.S. copyright law in 1961, the report contemplated four types of general exclusive rights: "(1) making and publishing copies, (2) making new versions, (3) giving public performances, and (4) making records of the work." 31 This was followed by a 1963 preliminary draft of legislation that collapsed three of those four rights (making copies, making new versions, and making records) into one exclusive right to copy and record protected works in any tangible form. ${ }^{32}$ That new right specifically would have encompassed "a translation, adaptation, or any other derivative work." ${ }^{33}$ The 1964 draft bill separated the exclusive right to prepare derivative works from the reproduction right. ${ }^{34}$ The Register explained that even though a separate derivative work right might seem unnecessary because the reproduction right "is broad enough to include adaptations and recast versions of all kinds, .... this has long been looked upon as a separate exclusive right, and to omit any specific mention of it would be likely to cause uncertainty and misunderstanding." 35

The Register did not, however, explain why this newly generalized exclusive right was designated as a derivative work right. One might have expected the Register to propose an adaptation right, which is the closest analogue in national copyright laws around the world. ${ }^{36}$ An adaptation right would have satisfied the

30. Copyright Act of $1909 \S 1$ (b).

31. House Comm. ON THE Judiciary, 87Th CONG., COPYRight LaW Revision: Report of the Register of Copyrights on the General Revision of the U.S. Copyright Law 24 (Comm. Print 1961). The 1909 Act had granted authors of literary works the right to make new versions of their works. Copyright Act of $1909 \S 1(\mathrm{~b})$.

32. See House Comm. on the Judiciary, 88th Cong., Copyright law Revision Part 3: Preliminary Draft for Revised U.S. Copyright law and Discussions and Comments on the Draft \& 5(a) (Comm. Print 1964). The preliminary draft, like its 1961 counterpart in the Register's Report, would have granted a right to control public performances of protected works, id. § $5(\mathrm{c})$, but it would also have added a new right to control distribution of copies, id. $\S 5(\mathrm{~b})$, and to exhibit pictorial, graphic, and sculptural works, $i d . \S 5(\mathrm{~d})$.

33. Id. §5(a).

34. See H.R. 11947, 88th Cong. (2d Sess. 1964); S. 3008, 88th Cong. (2d Sess. 1964). The derivative work right appeared as a separate provision again in 1965. See H.R. 4347, 89th Cong. (2d Sess. 1965); S. 1006,89 th Cong. (2d Sess. 1965).

35. House Comm. on the Judiciary, 89th Cong., Copyright Law Revision Part 6: Supplementary Report of the Register of Copyrights on the General Revision of the U.S. Copyright Law: 1965 Revision Brtl 17 (Comm. Print 1965).

36. See, e.g., Gervais, supra note 16, at 789-90; Paul Goldstein, Adaptation Rights and Moral Rights in the United Kingdom, the United States and the Federal Republic of Germany, 14 INT'L REv. Indus. Prop. \& Copyright L. 43, 43 (1983). The Berne Convention, like the 1909 Act, lists certain specific types of derivatives that member states should protect: translations (article 8); adaptations, arrangements, and other alterations (article 12); and cinematographic adaptations (article 14). Berne Convention for the Protection of Literary and Artistic Works, Sept. 9, 1886, S. TrEATY Doc. No. 99-27 (revised on July 24, 1971, and amended on Sept. 28, 1979) [hereinafter Berne Convention]. The United 
simplification and clarification goals for the revised U.S. exclusive-rights provision at least as well as a derivative work right-and perhaps better-because its contours could have been guided by precedents and commentary interpreting that right outside the United States. Yet, an adaptation right, as such, was never seriously considered in the copyright revision process.

So where did the derivative work right come from? Careful study of the legislative history of the 1976 Act reveals that the exclusive right to prepare derivative works was a logical outgrowth of the Register's efforts to grapple with some copyrightability and scope-of-protection issues that had been problematic under the 1909 Act. That Act had extended copyright protection to compilations, abridgements, adaptations, arrangements, dramatizations, translations, and other versions of works without explicitly saying that these works had to embody original expression to qualify for protection. ${ }^{37}$ The drafters of the revision bills were determined to make sure that these types of works would be eligible for protection only if their authors satisfied copyright's originality requirement. ${ }^{38}$ The drafters also wanted to coin a concise term to cover the types of adaptations that should be eligible for copyright protection so that it would not be necessary to name them individually, as the 1909 Act had done. ${ }^{39}$

The 1961 Register's Report addressed these problems by recommending that the statute explicitly state that "new versions of preexisting works" had to be "original" to qualify for copyrightable works of authorship. ${ }^{40}$ Concerns arose, however, about whether the use of "new" in this context would be confusingpossibly introducing a patent-like novelty standard instead of the conventional

States was the first country to adopt an exclusive right to prepare derivative works as such, rather than follow Berne Convention language. See J.A.L. STERLING, WORLD CopYright Law $\$ 6.21$ (3d ed. 2007) (describing the term "derivative works" as "deriving from U.S. copyright law"); Gervais, supra note 16, at 816-21 (discussing the right of adaptation in the Convention); id. at 789 n.14 (observing that the term "derivative works" appears only in the heading of Article 2(3) of the Convention). A few countries, such as Israel and South Korea, adopted derivative work rights in their national laws after 1980. See, e.g., Tony Greenman, Israel, in 1 Copyright Throughout the Worl.d § 20:17 (Silke von Lewinski ed., 2012); Jay (Young-June) Yang \& Chang-Hwan Shin, Korea, in 2 InTERnational CopyRIGHT LAW AND PRACTICE, at KOR-8 (Paul Edward Geller ed., 2012).

37. See Copyright Act of 1909, Pub. L. No. 60-349, § 6, 35 Stat. 1075, 1077 (repealed 1976); see also House Comm. on the Judiciary, 87th Cong., Copyright Law Revision: Report of the Register of Copyrights on the General Revision of the U.S. Copyright Law 9 (Comm. Print 1961) ("What the present statute fails to make clear is the basic requirement that the new elements must in themselves represent original creative authorship.") The sweat-of-the-brow-compilation copyright cases relied in part on the omission of an originality requirement in this provision. See, e.g., Hartfield v. Peterson, 91 F.2d 998, 999 (2d Cir. 1937); Jeweller's Circular Publ'g Co. v. Keystone Publ'g Co., 281 F. 83, 88 (2d Cir. 1922); Yale Univ. Press v. Row, Peterson \& Co., 40 F.2d 290, 291-92 (S.D.N.Y. 1930).

38. House Comm. on the Judiciary, 88th Cong., Copyright Law Revision Part 3: Preliminary Draft for Revised U.S. Copyright Law and Discussions and Comments on the Draft 65-66 (Comm. Print 1964) (describing concerns about "new versions").

39. Recall that in the $1963 \mathrm{draft}$, the reproduction right would have included "translations, adaptations, and other derivative works." See supra note 33 and accompanying text. An obvious way to simplify this text was to define derivative work to include the other two terms.

40. House Comm. on the Judiciary, 87th Cong., Copyright Law Revision: Report of the Register of Copyrights on the General Revision of the U.S. Copyright Law 10 (Comm. Print 1961). 
originality standard-and about what kind of originality these new versions should be expected to have. ${ }^{41}$

The 1963 preliminary draft dealt with the copyrightability concerns by proffering a new subject-matter provision that said that compilations and derivative works were eligible for copyright protection if they were original works of authorship in their own right. ${ }^{42}$ This provision also distinguished between the originality to be expected in compilations (for example, creative selection and arrangement of elements) and in derivative works (for example, creative adaptations). ${ }^{43}$ This subject matter provision defined "derivative work" as "a work based and dependent for its existence upon one or more pre-existing works, such as a translation, arrangement, instrumentation, abridgment, summary, index, dramatization, motion picture version, sound recording, art reproduction, or any other form of adaptation by which the work of an author may be recast or transformed." 44

The subject-matter provision also addressed three other derivative work issues. It stated that a copyright in a derivative work extended only to the original material that its author had contributed to the work. ${ }^{45}$ It clarified that copyright protection for a derivative work had no effect on the scope, duration, ownership, or validity of copyright in the underlying work. ${ }^{46}$ And it specified that derivative work copyrights were only available to authors whose creative adaptation of expression from underlying works was lawful. ${ }^{47}$

Although the 1963 preliminary draft had subsumed authorial control over translations, adaptations, and other derivative works within the reproduction right, the drafters' commitment to the term "derivative work" to address copyrightability and scope issues made it almost inevitable that this term would be adopted in a revised exclusive-rights provision when the bill ultimately separated the reproduction and derivative work rights, as happened in $1964 .{ }^{48}$

It made no sense to define the term "derivative work" twice, once to indicate which works, if original, qualified for protection and a second time to say which kinds of unauthorized derivatives could infringe the new exclusive right. The definition of "derivative work" thus needed to be moved out of the subjectmatter provision so that it could perform a more generalized set of functions. ${ }^{49}$

41. House Comm. on the Judiciary, 88th Cong., Copyright Law Revision Part 3: Preliminary Draft for Revised U.S. Copyright Law and Discussions and Comments on the Draft $65-66$ (Comm. Print 1964).

42. Id. §2(a).

43. Id. $\$ 2(\mathrm{c})-(\mathrm{d})$.

44. Id. \$2(d).

45. Id. $\S 2(\mathrm{~b})$.

46. Id.

47. Id. §2(a). Making a derivative of a public domain work and getting permission to make a derivative of an in-copyright work are examples of such lawful uses.

48. See supra note 34 and accompanying text.

49. Meeting transcripts indicate that the definitional text was included in the subject-matter section for the sake of clarity during discussion and "could well be put in another section of definitions." House 
The subject-matter-oriented definition also needed to be revised so that it would not inadvertently give rise to inappropriate liability. It was one thing to say, as the 1963 draft had done, that indexes and summaries were among the types of derivatives that, if original, would qualify for copyright protection, but quite another to say that the unauthorized preparation of an index or summary was a prima facie infringement of the derivative work right. To avert this risk, "index" and "summary" were both dropped from the definition. ${ }^{50}$

The 1964 and 1965 copyright revision bills substantially reorganized the provisions related to derivative works. The definition of "derivative work" was moved to a general definitional section. ${ }^{51}$ The revised subject-matter provision stated simply that copyright protection was available for original works of authorship fixed in a tangible medium of expression. ${ }^{52}$ A new section clarified that compilations and derivative works were eligible for copyright protection under the subject-matter provision, but that protection was unavailable to any part of those works that incorporated infringing material. ${ }^{53} \mathrm{~A}$ related provision clarified that copyrights in compilations and derivative works extended only to the original material contributed by their authors and were independent of and had no effect on the scope, duration, ownership, or subsistence of copyright in preexisting material. ${ }^{54}$ And finally, authors were granted an exclusive right to control the preparation of derivative works. ${ }^{55}$

As the Register had hoped, this new derivative work right simplified the statute. It was more expansive than the 1909 Act in that authors of all types of protected works would now be eligible for derivative rights in contrast to the 1909 Act's grant to authors of certain types of works and then only for specific types of derivatives. There is, however, no evidence in the legislative history that Congress intended an unlimited expansion of the scope of the right. ${ }^{56}$

Comm. on the Judiciary, 88th Cong., Copyright law Revision Part 3: Preliminary Draft for Revised U.S. Copyright Law and Discussions and Comments on the Draft 67 (Comm. Print 1964).

50. Id. at 72-73 (expressing concern about the inclusion of "index" in the derivative work definition because there were important policy reasons for scholarly indexing to be deemed noninfringing). By 1964, the definition of "derivative work" in the copyright revision bills omitted indexes and summaries. H.R. 11947, 88th Cong. $\S 54$ (2d Sess. 1964); S. 3008, 88th Cong. $§ 54$ (2d Sess. 1964). The revised wording remains in the 1976 Act. 17 U.S.C. \$ 101 (2006).

51. See H.R. 4347, 89th Cong. § 101 (2d Sess. 1965); S. 1006, 89th Cong. § 101 (2d Sess. 1965);

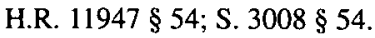

52. See H.R. 4347 § 102; S. $1006 \S 101$; H.R. 11947 § 1; S. 3008 § 1.

53. See H.R. $4347 \S 103(\mathrm{a})$; S. $1006 \S 103(\mathrm{a})$; H.R. $11947 \S 2$ (a); S. 3008 §2(a). It is worth noting that the U.S. rule deviates from the international norm in this respect. See, e.g., David Vaver, Abridgments and Abstracts: Copyright Implications, 5 Eur. INTELL. Prop. Rev. 225, 229 (1995).

54. See H.R. 4347 § 103(b); S. 1006 \& 103(b); H.R. 11947 \& 2(b); S. 3008 \& 2(b).

55. See H.R. 4347 § 106(a)(2); S. $1006 \S 106(a)(2) ;$ H.R. 11947 § 5(a)(2); S. 3008 §(a)(2).

56. One publisher wanted the derivative work right to cover more than adaptations. See HousE Comm. on the Judiciary, 89th Cong., Copyright Law Revision Part 5: 1964 Revision Blll with Discussions and Comments 216 (Comm. Print 1965) (transcribing comments of Bella L. Linden, American Textbook Publishers Institute: "With respect to the definition of 'derivative work[,'] I think the word 'adaptation' ... cuts down rather than amplifies the intention of including in a 'derivative work' any work 'based upon' one or more pre-existing works. This suggests the requirement of an 
The new definition of "derivative work" began as before-"a work based upon one or more preexisting works"-followed by a set of examples to illustrate the types of derivatives Congress intended to be within the right"such as a translation, musical arrangement, dramatization, fictionalization, motion picture version, sound recording, art reproduction, abridgement, [or] condensation." 57

The inclusion of translations, dramatizations, musical arrangements, and sound recordings as exemplary derivatives was unsurprising given that the 1909 Act had already covered such grants. ${ }^{58}$ Fictionalizations and motion-picture versions, although not explicitly mentioned in the 1909 Act, were likely within the exclusive right to make "any other version" of literary works. ${ }^{59}$ Art reproductions, abridgements, and condensations might have seemed unnecessary in the definition given that unauthorized creation of them would be covered by the reproduction right. ${ }^{60}$ These three examples were perhaps hangovers from the

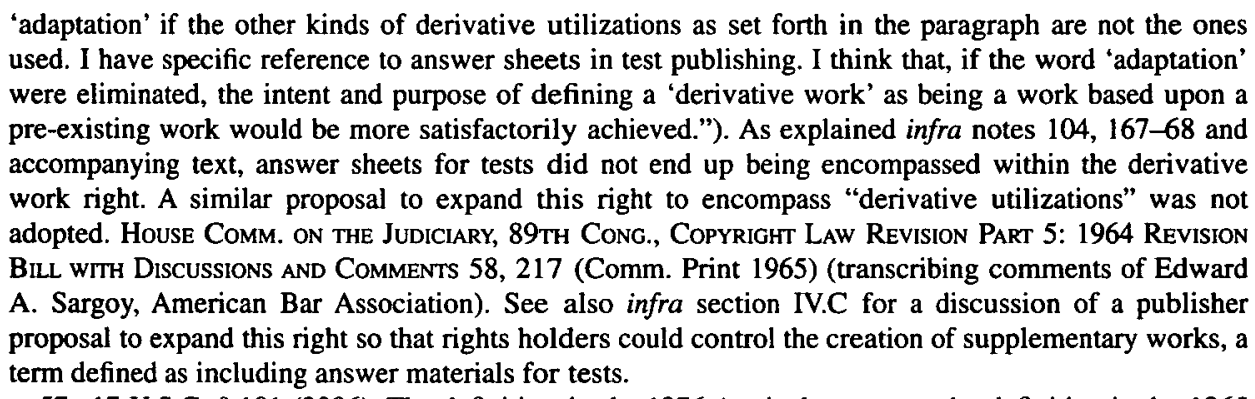

57. 17 U.S.C. $\$ 101$ (2006). The definition in the 1976 Act is the same as the definition in the 1965 bill. See H.R. $4347 \S 102$; S. $1006 \S 101$. The 1976 Act definition goes on to say that "[a] work consisting of editorial revisions, annotations, elaborations, or other modifications which, as a whole, represent an original work of authorship, is a "derivative work."' 17 U.S.C. $\$ 101$. That the editorial revision statement pertains to the copyrightability function of the derivative work definition, not to the exclusive right function, is evident from its structure, but also from the close similarity to the subject-matter-provision definition of the term in the 1963 preliminary draft.

58. See Copyright Act of 1909, Pub. L. No. 60-349, § 1(b)-(e), 35 Stat. 1075, 1075-76 (repealed 1976).

59. See id. § 1(b). Motion-picture versions of novels were analogized to the 1909 Act right to dramatize a work. See, e.g., Kalem Co. v. Harper Bros., 222 U.S. 55, 62 (1911) (holding that a motion-picture version of Ben Hur dramatized and thereby infringed copyright in the book). Fictionalization was analogous to converting a dramatic work into a novel. See, e.g., Greenbie v. Noble, 151 F. Supp. 45, 60 (S.D.N.Y. 1957) (holding that biographer had the right to control conversion of her work to a novel). A participant in a 1964 discussion session urged the addition of fictionalization because movie and television contracts often refer to this type of derivative. HousE COMM. ON THE Judiciary, 88th Cong., Copyright Law Revision Part 3: Preliminary Draft for Revised U.S. Copyright Law and Discussions and Comments on the Draft 80 (Comm. Print 1964) (transcribing comment of Stanley Rothenberg).

60. Abridgements had been among the subject matter eligible for copyright protection under section 7 of the Copyright Act of 1909. Condensations were not included in the 1964 definition and were seemingly added to the 1965 definition at the behest of some industry organizations. See, e.g., House Comm. on the Judiciary, 89Th Cong., Copyright law Revision Part 5: 1964 Revision Brll with Discussions and Comments 228 (Comm. Print 1965) (comment submitted by the American Book Publishers Council and the American Textbook Publishers Institute suggesting, inter alia, the addition of "condensation" to the list of exemplary works under the "derivative work" definition). For a 
first purpose of the definition, that is, to ensure that these kinds of works, if original, were eligible for copyright protection.

The drafters could have given more than nine examples in the definition, but nine was enough to illustrate the kinds of derivatives that were intended to fall within the right. It was simply not possible to identify all possible derivative uses that copyright owners should be able to control, especially given that the advent of new technologies would likely expand the future range of foreseeable derivatives. So the sensible strategy was to define derivative work with a sufficient set of examples to illustrate the kinds of derivatives that should be within the right and to provide some leeway for future evolution through the final clause: "or any other form in which a work may be recast, transformed, or adapted." 61

\section{The Derivative Work Right Covers the Nine Examples and Close Analogues}

Examining the evolution of the provisions of the copyright revision bills related to derivative works and reflecting on the simplification and clarification goals of the exclusive-rights provision provide some insights into the legislative intent underlying the novel derivative work right. Although the definition was initially intended to address copyrightability issues, it took on the new and even more important function of clarifying the scope of the exclusive right. ${ }^{62}$ It is significant that the syntax of the definition remained unchanged after its first incarnation in the preliminary draft, and but for certain excisions in 1964 that narrowed the scope of the right, the definition remained unchanged and uncontroversial during the legislative process.

In light of this history, the most plausible interpretation of the definition of derivative work in terms of its implications for the scope of the exclusive right is to view the definition as a whole with all component parts understood in relation to each other. Construing the definition holistically, it becomes apparent that the last clause, "or any other form in which the work is recast, transformed, or adapted," should be construed in light of the nine exemplary derivatives. Section A discusses key characteristics of the nine exemplary derivatives and explains the three clusters of derivative uses that the nine exemplify. Section B considers several types of derivative uses that are similar enough to the exemplary derivatives that they should generally be within the scope of the derivative work right. Section $C$ argues that derivative uses of protected works should be

discussion of how U.S. and British Commonwealth copyright laws have treated abridgments, condensations, and abstracts, see Vaver, supra note 53, at 225-29.

61. 17 U.S.C. $\$ 101$.

62. Although the term "derivative work" was originally defined in the revision bills to identify types of derivatives that could, if original, qualify for copyrights, there has been no litigation under the 1976 Act on whether unnamed derivatives can be copyrighted. Thus, the copyrightability function of the definition is no longer important. The definition has thus become important only for its infringement function. 
regulated under the last clause of the definition only if they are analogous to the nine exemplary derivatives. This interpretation of the derivative right is not only consistent with the text of the statute and the legislative history but also with the constitutional purpose of copyright, which is to promote the ongoing creation and dissemination of knowledge. ${ }^{63}$

\section{A. CHARACTERISTICS OF THE NINE EXEMPLARY DERIVATIVES}

Relatively little attention has been given in the case law or the law-review literature to some characteristic features of the nine exemplary derivatives in the 1976 Act definition. At first blush, they seem a hodgepodge. Translation is listed first, followed by musical arrangement and then by dramatization and fictionalization. Sound recording and art reproduction are interposed between motionpicture version and abridgement, which is followed by condensation. One reason for the seemingly arbitrary nature of the examples may be the dual purpose of the definition (to identify types of works that are copyrightable and to indicate types of works that may infringe).

The nine examples seem less anomalous if one clusters them into three main categories. Abridgements and condensations represent shorter versions of works on which they are based. Translations and art reproductions generally aim to be faithful renditions of the works on which they are based. Fictionalizations, dramatizations, motion-picture versions, sound recordings, and musical arrangements involve transformation of original expression from works on which these derivatives are based, often involving transformations from one medium to another or from one genre to another.

\section{Shorter Versions}

Abridgements and condensations are exemplary derivatives that operate in the same medium and genres as the works upon which they are based. ${ }^{64}$ Although these two types of derivatives are similar, they are not exactly the same. Abridgements involve iterative copying of substantial portions of the underlying work. Condensations may also involve iterative copying, but even if a condensation uses different words than an abridgement, the degree of similarity between the original and a condensed work is likely to be substantial. Abridgements and condensations may be targeted to readers who would be disinclined to consume a much longer, more detailed work. To that extent, they

63. See, e.g., Christopher Sprigman, Indirect Enforcement of the Intellectual Property Clause, 30 Colum. J.L. \& ARTs 565, 585 (2007) (arguing that statutes should be construed in light of the constitutional purposes of intellectual property).

64. See, e.g., Merriam-Webster's Colleglate Dictionary (11th ed. 2004) (including a definition of "abridge" as "to shorten by omission of words, without sacrifice of sense" and a definition of "condensed" as "reduced to a more compact or dense form"); see also Twin Peaks Prods., Inc. v. Publ'ns Int'l, Ltd., 996 F.2d 1366, 1375 (2d Cir. 1993) ("'A]n abridgement is a 'condensation; contraction. An epitome or compendium of another and larger work, wherein the principal ideas of the larger work are summarily contained." (quoting 1 BouviER's LaW DictionaRY 91 (3d rev. 1914)). 
may operate in a different market segment. Yet, abridgements and condensations are likely to supplant demand for the original as to a nontrivial set of consumers. ${ }^{65}$ These types of derivatives represent foreseeable market opportunities, which may play a role in providing incentives to authors of the underlying works.

\section{Faithful Renditions}

Translations and art reproductions are types of derivative works whose authors' principal goal is generally to provide a faithful rendition on a word-byword, line-as-line, or stroke-by-stroke basis of the whole of the underlying work. ${ }^{66}$ Authors of these derivatives typically operate in the same genres as the works upon which they are based, although not necessarily in the same mediums.

These faithful renditions are mainly intended for a different segment of the market than the original, although there may be some market overlap between the original and the derivative for some consumers. For example, unauthorized translations pose some risk of supplanting demand for the original for multilingual persons. Yet, for most consumers, the original work and a translation do not compete in the same market.

Nor do art reproductions generally operate in the same part of the art market as originals. Art reproductions pose a relatively modest risk of supplanting demand for originals. ${ }^{67} \mathrm{It}$ is possible, for instance, that some consumers might be willing to pay $\$ 200$ for an original if a $\$ 10$ poster was unavailable. However, for many art lovers, demand may exist only for originals, and art reproductions may mainly appeal to more financially constrained consumers. ${ }^{68}$

Unauthorized translations or art reproductions are generally more likely to supplant demand for authorized derivatives than to supplant demand for the original. Authors of the original works may expect to recoup some investment from exploiting the foreseeable translation and art-reproduction markets or may feel that others should not be unjustly enriched by these types of recastings of their works.

65. See, e.g., Twin Peaks, 996 F.2d at 1377 (holding a book of detailed plot summaries of TV show episodes as possibly impairing the market for the original work itself); Folsom v. Marsh, 9 F. Cas. 342, 349 (C.C.D. Mass. 1841) (No. 4901) (holding an abridgment of volumes of George Washington's letters took material "of most interest and value to the public" from the original); see also Vaver, supra note 53 , at 228 .

66. See, e.g., Jiří Levý, The Art of Translation 60 (Patrick Corness trans., 2011) ("Two norms apply in the evolution of reproductive art-the reproduction norm (i.e. the requirement to capture the original faithfully) and the 'artistic' norm (i.e. the requirement of beauty).").

67. See, e.g., NAOMI Z. Sofer, MAKING thE "AMERICA OF ART": Cultural Nationalism AND NineteEnTHCentury Women Wrrters 128 (2005) ("[T]he market for lithographs, good-quality full-color reproductions that sold for 'the price of a pair of slippers,' is entirely different from the market for original art, and ... one does not cannibalize the other...." (quoting James Parton, Popularizing Art, ATLANTIC MONTHLY, Mar. 1869, at 355)).

68. Id. 


\section{Transformations of Expression from One Medium or Genre to Another}

Dramatizations and motion-picture versions transform expressive elements of the plot, structure, characters, narrative thread, and the like of the underlying work to a different medium. Often, numerous changes are necessitated by the change in medium. ${ }^{69}$ The interior design of a room in which key actions take place may, for instance, be described in words in a novel but will be depicted visually in a dramatization or motion-picture version of the novel.

Changes in medium have implications for the markets for the underlying and derivative works. The primary market for a dramatization (stage performances) is quite different than the primary market for a novel (sales of copies). Motionpicture derivatives of novels may be exploited by theatrical performances, television broadcasts, and sales of DVDs or the like. ${ }^{70}$ These exploitations may be unlikely to supplant demand for copies of the original book. In some cases, motion-picture versions of a book may create positive demand for the original version. ${ }^{71}$ A key factor in this type of derivative work analysis is whether an unauthorized derivative will supplant demand for an authorized dramatization or motion-picture version of the literary work. ${ }^{72}$

Fictionalization ${ }^{73}$ is another derivative that will implicate the derivative work right insofar as it transposes expression from the work upon which it is based. A history or a biography may inspire a second author to fictionalize episodes from the lives of persons discussed in the underlying work. As long as the fictionalization draws only upon the facts or research materials from the nonfiction work, infringement of the derivative work right is unlikely. ${ }^{74}$ Yet an unusual chronology of events or the same selections from letters might be among the expressive elements of a nonfiction work that might give rise to derivative work liability if carried over into an unauthorized fictionalization. This kind of derivative may be unlikely to supplant demand for the original work, but as with dramatic and motion-picture derivatives, they may more often undercut demand for an authorized derivative.

Musical arrangements also transform expression from preexisting works. ${ }^{75} \mathrm{~A}$ rearrangement may recast the original music in a different genre (say, jazz or

69. See, e.g., Douglas Y'Barbo, Aesthetic Ambition Versus Commercial Appeal: Adapting Novels to Film and the Copyright Law, 10 ST. ThomAs L. Rev. 299, 348-49 (1998) (describing the adaptation process).

70. See, e.g., Paul Grainge, Brand Hollywood: Selling Entertainment in a Global Media Age 9 (2008).

71. See, e.g., Shubha Ghosh, Market Entry and the Proper Scope of Copyright, 12 INT'L J. EcoN. Bus. 347, 350 (2005); Y'Barbo, supra note 69, at 372.

72. See $Y^{\prime} B$ arbo, supra note 69 , at 375 .

73. One dictionary definition of "fictionalize" is "to make into or treat in the manner of fiction." Merriam-Webster's Colleglate Dictionary ( 11 th ed. 2004).

74. See, e.g., Hoehling v. Universal City Studios, Inc., 618 F.2d 972, 977 (2d Cir. 1980) (rejecting historian's claim that a movie about the Hindenberg disaster infringed copyright in his history book).

75. See, e.g., Vince Corozine, Arranging Music for the Real World: Classical and Commercial AsPECTS 3 (2002) (quoting the American Federation of Music definition of "arranging" as "preparing and adapting an already written composition for presentation in other than its original form"). 
bluegrass). Musical arrangements may operate in a different market segment than their originals. There is, however, more potential overlap in market segment with musical arrangements than with, say, translations. A jazz composition, for instance, may be transformed by a second jazz composer in a recognizable way, even if the details of the new rendition are noticeably different. Unauthorized musical arrangements may sometimes supplant demand for the original work as well as for authorized derivatives.

Sound recordings transpose the expression of musical works from one medium to another, although musicians today are more likely to "fix" their compositions in sound recordings rather than, as they did in the past, in written musical notations. The risks of supplanting demand, either for the underlying work or for authorized derivatives, are lower for sound recordings than for the other eight exemplary derivatives because of special rules affecting this type of derivative work. ${ }^{76}$

Table 1 presents a matrix to illustrate characteristics of each type of exemplary derivative, including the extent of expected fidelity to the original work, the medium in which the original and derivative appear, the overlap (if any) in the market segment of the original and each type of derivative, the risk (if any) of supplanting demand for the original in its primary market, and the risk (if any) that a certain type of unauthorized derivative might supplant demand for an authorized derivative.

Table 1 illustrates several points about the exemplary derivatives. First and most important, all nine are aimed at clearly foreseeable markets to the works on which the derivatives are based. ${ }^{77}$ Second, some exemplary derivatives exist in the same medium and operate in the same or an overlapping market segment as the original work. ${ }^{78}$ These derivatives have a high degree of expected fidelity

76. Once an authorized sound recording has been made of a musical work, U.S. copyright law authorizes others, by virtue of a compulsory license, to record the same music, subject to an obligation to pay a royalty to the owner of the copyright in the musical work. See 17 U.S.C. $\S 115$ (2006). Sound-alike sound recordings do not infringe the reproduction or derivative work rights of soundrecording copyrights. See 17 U.S.C. $\$ 114(\mathrm{~b})$. These rules lessen the risks that an unauthorized sound recording would lower demand for authorized originals.

77. Composers look to markets for sound recordings and rearrangements to recoup their investments in the creation of music. Novelists expect translations, dramatizations, and motion-picture versions to be derivative markets of their books. Nonfiction writers anticipate translations, fictionalizations, abridgements, and condensations of their works. Painters and sculptors may regard art reproductions as viable derivative markets. Although the derivative work right is no longer statutorily linked with particular types of works, the nine examples nevertheless generally remain limited by type. Musical arrangement is the most specific and obvious example. Art reproductions as derivative works seem applicable only to pictorial, sculptural, and graphic works. Fictionalization implies a nonfiction literary work as the based-upon work. Translations and dramatizations are likewise types of derivatives most likely to be undertaken with literary works. A translation right would make no sense as applied, for instance, to architectural works any more than pantomimes could be recast as sound recordings.

78. Professor Abramowicz asserts that derivative works "will rarely steal much business from the earlier original work" and "will almost never be a substitute for the earlier one." Michael Abramowicz, A Theory of Copyright's Derivative Right and Related Doctrines, 90 MinN. L. REv. 317,358 (2005). 
Table 1: Characteristics of the Nine Exemplary Derivatives

\begin{tabular}{|c|c|c|c|c|c|}
\hline $\begin{array}{c}\text { Type of } \\
\text { derivative }\end{array}$ & $\begin{array}{l}\text { Expected } \\
\text { fidelity? }\end{array}$ & $\begin{array}{l}\text { Same genre } \\
\text { or medium? }\end{array}$ & $\begin{array}{c}\text { Same } \\
\text { market? }\end{array}$ & $\begin{array}{c}\text { Risk of } \\
\text { supplanting } \\
\text { demand for } \\
\text { original? }\end{array}$ & $\begin{array}{l}\text { Risk of } \\
\text { supplanting } \\
\text { derivatives? }\end{array}$ \\
\hline Abridgement & high & same & some overlap & medium & high \\
\hline Condensation & high & same & some overlap & medium & high \\
\hline Translation & high & same & different & low & high \\
\hline Art reproduction & high & similar & some overlap & some risk & high \\
\hline Movie version & some & different & different & $\begin{array}{l}\text { some risk (possibly } \\
\text { higher in some } \\
\text { instances) }\end{array}$ & high \\
\hline Dramatization & some & different & different & $\begin{array}{l}\text { some risk (possibly } \\
\text { higher in some } \\
\text { instances) }\end{array}$ & high \\
\hline Fictionalization & some & same & different & $\begin{array}{l}\text { low (possibly } \\
\text { higher risk in } \\
\text { some instances) }\end{array}$ & high \\
\hline $\begin{array}{l}\text { Music } \\
\text { arrangement }\end{array}$ & some & mixed overlap & some overlap & some risk & high \\
\hline $\begin{array}{l}\text { Sound } \\
\text { recordings }\end{array}$ & some & mixed overlap & mixed overlap & low & low \\
\hline
\end{tabular}

to the original work and are hence easiest to characterize as derivative works. For these derivatives, there is some risk that unauthorized derivatives will supplant demand for the original. Third, there is only one type of exemplary derivative for which the risk is minimal that an unauthorized derivative in these readily foreseeable markets will supplant demand for authorized derivatives. ${ }^{79}$ Fourth, the exemplary derivatives generally involve the fixation of a second work in tangible form. ${ }^{80}$ Fifth, none involves the creation of a supplementary or complementary work.

Reflecting on the characteristics of the examples, we can discern that three principal features distinguish the derivative work right from the reproduction right: first, the derivative author contributes some original expression to the

\footnotetext{
Though this may be true for some types of derivatives, Table 1 suggests that some types of derivative works may have effects in the market in which the original work is being disseminated.

79. The exception is sound recordings for reasons explained supra note 76.

80. Musical arrangements may be an exception. A live jazz improvisation could rearrange music and thereby infringe the derivative work right, even though the rearrangement was not fixed in a tangible medium. Unauthorized public performances of musical works have sometimes been said to infringe the derivative work right. See, e.g., Nimmer \& Nimmer, supra note $25, \S 8.01$ [A]. Professor Ochoa has expressed concern that a broad interpretation of the derivative work right as applied to performances might subject private performances to copyright liability. Ochoa, supra note 24 , at $993-94$. To avoid this result, Ochoa recommends that the courts treat performances as infringing derivatives only insofar as the same acts would infringe the public-performance right. Id. at 1020 . I concur with Ochoa's conclusion on this point.
} 
derivative work he or she creates; ${ }^{81}$ second, the second work's expression is intermingled with expression from the underlying work, either transforming or rendering the first work's expression so that the new work is distinguishable from the underlying work; third, although the second work will rarely supplant the whole or a substantial part of demand for the underlying work, it is generally likely to supplant demand for authorized derivatives. ${ }^{82}$

\section{B. CLOSE ANALOGUES TO THE NINE EXAMPLES ARE DERIVATIVE WORKS}

The final clause of the derivative work definition, "or any other form in which a work may be recast, transformed, or adapted," provides flexibility so that analogous derivatives can be covered by the derivative work right. ${ }^{83}$ One category of close analogues includes sequels, prequels, or continuations of stories related in preexisting works. ${ }^{84}$ Even though the definition does not explicitly mention them, they should generally be within the reach of this right because they match up quite closely to characteristics of the definitional

81. Originality in an abridgement will lie in the selection and arrangement of expression from the first work. Originality in an art reproduction is likely to reside in the second artist's transposition of expression from the underlying work rendered in a different medium. See, e.g., Alfred Bell \& Co. v. Catalda Fine Arts, Inc., 191 F.2d 99 (2d Cir. 1951) (upholding copyright in mezzotints based on public domain paintings).

82. I agree with Professor Gervais that the derivative work right is conceptually distinct from the reproduction right. See Gervais, supra note 16, at 834 ("[T] he difference lies in the transfer of elements of original expression from the primary work to the derivative one for the purpose of adding or transforming it, but not to the point of a fundamental transformation of the primary work...." (emphasis omitted)). Professor Goldstein has noted that a sharp line between reproductions and derivative works may not exist. See Paul Goldstein, Derivative Rights and Derivative Works in Copyright, 30 J. COPYRIGHT Soc'y USA 209, 217 n.29 (1983) (indicating that in borderline cases, this "distinction is best resolved according to the comparative degree to which the infringing work belongs to one category rather than the other: the degree to which it adds expressive elements to the underlying work and the degree to which it serves a market different from the market for the underlying work"). Professor Tushnet has recently proposed that the reproduction right should be reserved for cases involving exact or near-exact copying and that the derivative work right should address substantial similarity cases with a focus on market effects. See Rebecca Tushnet, Worth a Thousand Words: The Images of Copyright, 125 HARV. L. REv. 683, 687 (2012). The legislative history of the 1976 Act offers one other distinction between the reproduction and derivative work rights, saying that the former can only be infringed if there is a copy fixed in a tangible medium, whereas the latter can be infringed by an unfixed performance. H.R. REP. No. 94-1476, at 62 (1976). See supra note 80 regarding Professor Ochoa's reservations about treating private performances as possible infringements of the derivative work right.

83. 17 U.S.C. $\S 101$ (2006). Four of the derivative rights under the 1909 Act have no counterpart in the 1976 Act definition: other versions of literary works, converting dramatic works to novels, finishing works of art from models or designs, and transcribing a dramatic work. Compare Copyright Act of 1909, Pub. L. No. 60-349, § 1(b), 35 Stat. 1075, 1075 (repealed 1976), with 17 U.S.C. $\$ 101$. The omission of these derivative uses from the 1976 Act definition should not be understood as manifesting an intent to exempt them from liability but rather as additional derivative uses that are within the derivative work right's last clause because they are closely analogous to the nine examples.

84. See, e.g., Abramowicz, supra note 78, at 318, 326 (noting that sequels are within the derivative work right). But see Newman, supra note 24, at 307 (questioning whether sequels should be within the derivative work right). Perhaps the right rule is that sequels or prequels should not automatically be presumed infringing derivative works but that they are more likely to be when the second comer appropriates a substantial number of expressive details from the first work. 
examples. Sequels, prequels, or continuations typically exist in the same medium as the underlying work, typically aim to operate in the same market segment as the original work, and, in fact, typically attract the same consumers as the original work did. ${ }^{85}$ Although sequels, prequels, and continuations may be unlikely to supplant demand for the original work, they may well inhibit demand for an authorized derivative. Authors of the underlying works may, moreover, need the time that the derivative work right provides to make sound decisions about whether to create these types of derivatives and how best to bring them into being. ${ }^{86}$ It is thus unsurprising that courts have been receptive to derivative work claims involving unauthorized sequels and the like. ${ }^{87}$

Retelling the same story from a different vantage point may also run afoul of the derivative work right, although in some cases, a critical retelling may be a fair use, as with Alice Randall's recasting of events and characters from Gone with the Wind from a slave's viewpoint ${ }^{88}$ Parodies, satires, and similar transformations of preexisting works may similarly put an unauthorized transformer at some risk of infringing the derivative work right unless they too are fair uses. ${ }^{89}$ Parodists often appropriate for commercial purposes qualitatively substantial expressive parts of the highly creative works, and these factors would generally cut against a finding of fair use. ${ }^{90}$ The Supreme Court has, however, recognized:

Parody's humor, or in any event its comment, necessarily springs from recognizable allusion to its object through distorted imitation. Its art lies in the tension between a known original and its parodic twin. When parody takes aim at a particular original work, the parody must be able to "conjure up" at least enough of that original to make the object of its critical wit recognizable. ${ }^{91}$

85. Fan fiction is generally regarded as fair use of the works on which it is based. See, e.g., Chander \& Sunder, supra note 23, at 600; Rebecca Tushnet, Legal Fictions: Copyright, Fan Fiction, and a New Common Law, 17 Loy. L.A. ENT. L.J. 651,654 (1997).

86. The failure of an author to develop sequels, prequels, or continuations after a long period may be a factor weighing in favor of a fair use defense for a subsequent author who undertakes such an effort. See infra note 122.

87. See, e.g., Anderson v. Stallone, 11 U.S.P.Q.2d (BNA) 1161, 1167 (C.D. Cal. 1989) (holding that an outline for a sequel to the Rocky movies infringed the derivative work right).

88. See Suntrust Bank v. Houghton Mifflin Co., 268 F.3d 1257, 1277 (11th Cir. 2001).

89. See, e.g., Campbell v. Acuff-Rose Music, Inc., 510 U.S. 569, 593 (1994) (deeming a rap parody of a ballad to be a transformative fair use). Judge Leval provides a classic and influential exposition of the fair use doctrine. See Pierre N. Leval, Toward a Fair Use Standard, 103 Harv. L. Rev. 1105 (1990) (cited 13 times in Campbell). Campbell is discussed infra notes 156-61 and accompanying text. But see Dr. Seuss Enters., L.P. v. Penguin Books USA, Inc., 109 F.3d 1394, 1403 (9th Cir. 1997) (holding that a satirical use of tropes from The Cat in the Hat in a text about OJ Simpson was not a fair use). Campbell explained that parodies are more likely to qualify as fair uses because of the need for second comers to make use of expressive elements of the works they are parodying in order to engage in this form of critical commentary. Campbell, 510 U.S. at 579-80. Yet the Court recognized more clearly than the Ninth Circuit in the Seuss case that satires may also qualify as fair uses. Id. at 581 ; see also R. Anthony Reese, Transformativeness and the Derivative Work Right, 31 Colum. J.L. \& ARTs 467 (2007) (analyzing transformativeness in fair use and derivative work cases).

90. See Campbell, 510 U.S. at 581-88.

91. Id. at 588. Creative reworkings of other artists' works are discussed infra section V.C. 
Although courts have thus far been unreceptive to sound-recording artists who sample from prior recordings, these decisions have been criticized for failing to recognize impacts on ongoing innovation and free expression in the music industry. ${ }^{92}$

Other close analogues to the exemplary derivatives can be found in case law. Similar to abridgements and condensations are the unauthorized editing of a television program, writing a book containing detailed plot summaries of specific episodes of a particular television series, and regularly publishing summaries of the main findings of research reports about companies' prospects. ${ }^{93}$ Similar to an art reproduction is the making of three-dimensional toys based upon two-dimensional cartoon characters. ${ }^{94}$ Similar to dramatizations and motionpicture versions are composing a musical stage play based upon an old radio comedy series, creating a musical show based upon a novel, and developing radio scripts based upon television programs. ${ }^{95}$ Advances in technology have sometimes enabled the creation of analogous derivative works that Congress could not have anticipated in $1976 .{ }^{96}$

\section{CONSTRUING THE DERIVATIVE RIGHT IN LIGHT OF THE DEFINITIONAL EXAMPLES}

There are several reasons to believe that Congress put the nine specific types of derivatives in the statutory definition to exemplify and illustrate the kinds of derivatives it wanted rights holders to be able to control and that it did not intend to create an entirely open-ended right. For one thing, the simplification and clarification goals for the derivative work right could not be achieved if the

92. See, e.g., Kembrew Mcleod \& Peter DiCola, Creatrve license: The Law and Culture of Digrtal SAMPLING 240-43 (2011) (discussing the cases and impacts on artists and proposing reforms).

93. See, e.g., Twin Peaks Prods., Inc. v. Publ'ns Int'l, Ltd., 996 F.2d 1366, 1370 (2d Cir. 1993) (holding that a book summarizing plots and reproducing some dialogue of the Twin Peaks television series infringed copyright); Wainwright Sec., Inc. v. Wall St. Transcript Corp., 558 F.2d 91, 93-94 (2d Cir. 1977) (holding that systematic publication of excerpts of key findings from research reports infringed); Gilliam v. Am. Broad. Cos., 538 F.2d 14, 17-19, 23 (2d Cir. 1976) (holding that broadcasting unauthorized edits of Monty Python programs on TV beyond ABC's license infringed the copyright of the scripts); see also WGN Cont'1 Broad. Co. v. United Video, Inc., 693 F.2d 622, 628 (7th Cir. 1982) (holding that a cable company's deletion of teletext when retransmitting plaintiff's broadcast program and substitution of alternative text constituted infringement).

94. King Features Syndicate v. Fleischer, 299 F. 533, 538 (2d Cir. 1924) (holding that threedimensional toys based upon cartoon characters infringed). Analogous perhaps to translations might be the compilation of source code to produce machine-executable object code. See, e.g., Michael F. Morgan, The Cathedral and the Bizarre: An Examination of the "Viral" Aspects of the GPL, 27 J. MARSHALl J. CoMputer \& INFo. L. 349, 408-09 (2010) (suggesting that object code may be a derivative work of source code).

95. See, e.g., Silverman v. CBS Inc., 870 F.2d 40, 50 (2d Cir. 1989) (holding that a musical infringed copyright in Amos ' $n$ ' Andy radio scripts); Lone Ranger Television, Inc. v. Program Radio Corp., 740 F.2d 718, 726 (9th Cir. 1984) (holding that radio scripts infringed rights in TV programs); Metro-Goldwyn-Mayer, Inc. v. Showcase Atlanta Coop. Prods., Inc. 479 F. Supp. 351, 361 (N.D. Ga. 1979) (holding that a musical show based on Gone with the Wind infringed the book's copyright).

96. See, e.g., Greenberg v. Nat'l Geographic Soc'y, 244 F.3d 1267, 1275 (11th Cir. 2001) (holding that an animation sequence in an electronic compilation of National Geographic magazines featuring photographs morphing into one another was an unauthorized derivative work). 
last clause, "or any other form in which the work has been recast, transformed, or adapted," was unbounded. ${ }^{97}$ Had Congress intended to make the derivative work right completely open-ended, it would not have defined the term at all or would have defined it without the examples as "any work that recasts, transforms or adapts a pre-existing work." Nor would the legislative history have included limiting statements such as this: "to constitute a violation of [the derivative work right], the infringing work must incorporate a portion of the copyrighted work in some form." 98

Although the last clause of the definition of derivative work is open-ended enough to cover analogous uses and to accommodate new types of adaptations made possible by technology, the definition should be construed as a whole. ${ }^{99}$ It should not be construed as if it was actually two separate definitions conjoined at the hip, one that encompasses the examples and the last clause for everything else. The nine examples should instead be understood as providing some guidance about what the last clause means.

Indeed, during the legislative debate, several copyright-industry representatives expressed concern that use of "such as" in the derivative work and other copyright definitions would have a limiting effect on judicial interpretations of the terms under the ejusdem generis canon of statutory construction. ${ }^{100}$ Some industry representatives proposed specific changes to make the definition of derivative work more open-ended and less susceptible to ejusdem generis limitations, but these suggestions were not adopted. ${ }^{101}$

97. 17 U.S.C. $\$ 101$ (2006); see supra note 29 and accompanying text.

98. See H.R. Rep. No. 94-1476, at 62 (1976) (emphasis added). This Report went on to say that "a detailed commentary on a work or a programmatic musical composition inspired by a novel would not normally constitute infringements under this clause." Id.

99. Professors Bohannan and Hovencamp also argue that the last clause of the derivative work right should be construed in light of the examples. See Christina Bohannan \& Herbert Hovenkamp, Creation Without Restraint 222-24 (2012). I agree with them that both competition and free speech policy support a narrow interpretation of this right. See id. But for reasons explained in this Article, I believe that the text, legislative history, and constitutional purpose cabin the reach of the derivative work right.

100. House Comm. on the Judiciary, 89th Cong., Copyright Law Revision Part 5: 1964 Revision Bill. with Discussions and Comments 38-39, 215, 217 (Comm. Print 1965) (transcribing comments of Edward Sargoy, American Bar Association, and Horace Manges, American Book Publishers Council). Ejusdem generis, meaning "of the same kind," is a canon of statutory construction. In construing a statute, when general words follow a designation of particular subjects or classes, the meaning of the general words will ordinarily be presumed to be restricted by the particular designations and as including only things or persons of the same kind, class, character, or nature as those specifically enumerated unless a contrary intention is clearly shown. See, e.g., 73 AM. JuR. 2D Statutes § 126 (2012); 82 C.J.S. Statutes $\$ 438$ (2012); see also 2A Norman J. Singer \& J.D. Shambie Singer, Sutherland StatuTORY Construction $\$ \S 47: 17-: 22$ (7th ed. 2012) (discussing conditions under which ejusdem generis applies).

101. See, e.g., House Comm. on the Judiciary, 89th Cong., Copyright Law Revision Part 5: 1964 Revision Bill with Discussions and Comments 228 (Comm. Print 1965) (comment submitted by the American Book Publishers Council and the American Textbook Publishers Institute on Dec. 17, 1964, proposing that "such as" be deleted from the definition of derivative work and that "including but not limited to" be substituted for that phrase). Though the 1976 Act states that "such as" is intended to be 
Other evidence of an intent to limit the scope of the derivative work right comes from the decision to omit from the definition two terms, "index" and "summary," after the 1964 draft bill added the derivative work right to the exclusive-rights provision, as well as the rejection of industry proposals to broaden the reach of derivative rights by adding "supplementary works" to this exclusive right. ${ }^{102}$ The latter proposal was so overreaching that the Register was prompted to assert that no infringement of the derivative work right should be found unless some expression had "actually ... been appropriated" from the work alleged to be infringed. ${ }^{103}$ The Register also declined to adopt other broadening language proposed by industry groups. ${ }^{104}$

In sum, courts should be skeptical of novel derivative work claims. To be consistent with the statutory text, the legislative history, and the constitutional purpose of copyright law, copyright owners should have to show that any challenged derivative use of a copyrighted work is similar enough in characteristics to the nine exemplary derivatives to be fairly within the scope of the derivative work right. Had this approach been adopted in cases discussed in Part V, certain derivative work claims might not have succeeded.

\section{Three Justifications for the Grant of Derivative Work Rights}

The legislative history of the 1976 Act does not directly explain the rationale for granting authors a derivative work right. Drawing from insights of commentators on the derivative work right and from reflections on the exemplary derivatives, there seem to be three primary justifications for copyright law to grant some derivative work rights to authors. First, some works are created with the expectation that particular derivative markets are important to recouping investments in these works. ${ }^{105}$ In the absence of derivative work rights, some

"illustrative not limitative," see 17 U.S.C. $§ 101$, examples can be illustrative only if they have some connection to the other referents they are said to illustrate.

102. See supra note 50 and accompanying text (discussing the omission of indexes and summaries); infra note 165 and accompanying text (discussing the decision to not adopt an exclusive right to control supplementary works).

103. House Comm. on the Judiciary, 89th Cong., Copyright Law Revision Part 6: Supplementary Report of the Register of Copyrights on the General Revision of the U.S. Copyright LaW: 1965 Revision Bill 18 (Comm. Print 1965). Treatise authors and the case law have agreed that an appropriation of protectable expression is necessary before the derivative work right is infringed. See, e.g., NIMMER \& NiMMER, supra note 25, § 8.09[A] n.4 (quoting from the Register's supplementary report and citing cases).

104. Some publisher groups also wanted "and any work which is a dependent adjunct to an existing work" to be added to the definition of derivative work, mainly because they wanted the right to extend to test answer sheets. See House Comm. on the Judiciary, 89th Cong., Copyright Law Revision Part 5: 1964 Revision Bill with Discussions and Comments 228 (Comm. Print 1965) (emphasis omitted). In a separate comment, the American Textbook Publishers Institute objected to the removal from the revision bill of "and dependent for its existence upon" language to typify answer sheets, but this objection failed to persuade the drafters of the revised bill. Id. at 232-33.

105. Some commentators have suggested that the economic case for a derivative work right is weak. See, e.g., Bohannan \& HovenKamp, supra note 99, at 204 n.16; Lunney, supra note 24 , at 629 . Others have suggested that the economic case for such rights is "subtle." See, e.g., William M. LANDES \& 
valuable works might not be created or disseminated to the public. ${ }^{106}$ Second, the grant of a derivative work right gives authors some time to decide which derivative markets to enter, with whose assistance, on what terms, and when. ${ }^{107}$ Third, even though many works would be created without derivative work rights, Congress could reasonably have decided that the derivative work right would avoid unjust enrichment by unlicensed exploiters of foreseeable derivative markets. ${ }^{108}$ Close examination of each rationale suggests that each justifies a grant of control over exemplary and analogous derivatives to achieve the intended purposes, but not beyond them. Unless carefully cabined to the kinds of foreseeable markets exemplified by the definitional derivatives, this right can unduly restrain competition and follow-on innovation, as well as interfere with free-expression interests of subsequent creators.

\section{A. DERIVATIVE WORK RIGHTS ARE IMPORTANT TO INVESTMENTS FOR SOME CREATORS}

For some authors, derivative markets factor into decisions about whether to create new works and what kinds of works to create. Professor Goldstein has stated that "[d]erivative rights affect the level of investment in copyrighted works by enabling the copyright owner to proportion its investment to the level of expected returns from all markets, not just the market in which the work first appears." ${ }^{109}$ Producers of motion pictures are among those who consider derivative work rights in making decisions about whether to invest in these creations. ${ }^{110}$ Because movies are capital-intensive types of works to create and bring to market, derivative work rights have become quite important to the recoupment strategies of their producers. ${ }^{111}$ This often includes the possibility of sequels involving some or all of the same characters and some overlap in

Richard A. Posner, The Economic Structure of Intellectual Property Law 109-12 (2003). I agree that the economic case for an unbounded derivative work right is weak, but it is stronger for a bounded right.

106. See Goldstein, supra note 82 , at 227.

107. See Abramowicz, supra note 78 , at 319-20.

108. See Wendy J. Gordon, On Owning Information: Intellectual Property and the Restitutionary Impulse, 78 VA. L. REv. 149, 182 (1992) (discussing unjust enrichment as a rationale for some grants of intellectual property rights). Some commentators have discussed derivative work rights as potentially justifiable as a means to enable rights holders to engage in price discrimination. See, e.g., Lunney, supra note 24, at 630-31. This is more true for some types of derivatives (for example, an artist's sale of posters for $\$ 10$ and of the original painting for $\$ 10,000$ ) than others (for example, the translation of a novel from English to Finnish). Professors Landes and Posner suggest an additional justification for grants of derivative work rights to authors, namely, that this grant reduces transaction costs because there is one holder of these rights with whom potential reusers have to negotiate. LANDES \& POSNER, supra note 105 , at 111 . Other commentators question this justification. See, e.g., Bohannan \& HOVENKAMP, supra note 99, at 204 n.16; Sterk, supra note 24, at 1217.

109. Goldstein, supra note 82 , at 227 . Derivative rights may also "affect the direction of investment in copyrighted works." Id.

110. See, e.g., id. at 209-11, 217, 227.

111. Id. at 209 (pointing out that motion-picture studios sometimes earn more from merchandising than from theatrical performances of their movies). Professor Sterk questions Goldstein's argument for a broad derivative work right as to most copyrighted works. See Sterk, supra note 24, at 1215-16. 
plot, as well as merchandise depicting characters or scenes from the movie.

Movies are, however, far from the only type of copyrighted work created with derivative work rights in mind. Songwriters nowadays rarely expect to make much money from sales of sheet music. ${ }^{112}$ They typically compose songs in the expectation of making money from sales of sound recordings and licensing public performances. Architects prepare drawings with the goal of being commissioned to make further representations of their designs as well as to oversee the implementation of their designs in the derivative form of a building. ${ }^{113}$ Computer programmers expect to customize software to meet specific customer needs and to offer updated versions to the public. Sculptors and graphic artists often sketch or make models with the goal of eventually producing works of visual art. Sometimes these sketches or models are offered for sale at more modest prices than the final sculpture or graphic art envisioned in the sketch or model. Some graphic art, moreover, is created with the goal of making additional money from sales of art reproductions, such as postcards, posters, or other facsimiles, as artifacts through which the artist may recoup her investments.

Novelists and playwrights frequently expect their works to be transformed into movies or translated from one language to another. Screenwriters and novelists often anticipate having their works adapted for the stage. Although contemplation of derivatives may sometimes affect whether they choose to write at all, it may also affect the direction in which their writing may go. ${ }^{114}$ Some writers, for example, may be more inclined to write novels or plays of a sort or in a manner that will make them more marketable to movie studios.

Nonfiction writers are less likely to expect motion pictures to be made of their works, although biographies and histories have sometimes been adapted to documentaries. ${ }^{115}$ But nonfiction writers may have the same hope or expectation as novelists that their writings will prove popular enough to generate demand for translations or abridgements, especially for educational markets. These authors expect to have the right to control who prepares these derivatives. Some publishers may, moreover, take derivative markets into account in deciding whether to invest in works prepared by unknown authors.

112. Indeed, for many songwriters today, sheet music is likely to be a derivative market for music composed during recording sessions.

113. Constructing a building depicted in copyrighted architectural drawings will generally not infringe the derivative work right for drawings published before December 1, 1990, the effective date of the Architectural Works Copyright Protection Act of 1990. U.S. CopYright OfFICE, CoPYRIGHT Claims in Architectural Works 2 (2012). This is because the protected work is the design of the building, regardless of the form in which it is embodied. A building is only one manifestation of such a work. See 17 U.S.C. \$ 101 (2006) (defining “architectural work”).

114. Goldstein, supra note 82 , at 227.

115. A popular biography of John Adams by David McCullough was, for example, made into a television miniseries. See John Adams (HBO Films 2008). Martin Scorcese's movie Gangs of New York was based on a nonfiction work by Herbert Armstrong. See Gangs of New York (Miramax Films 2002). 
This is not to say that all or even most authors would decide against creating new works in the absence of derivative work rights. There are many songwriters, playwrights, novelists and scholars who create new works without thinking about derivative work rights. Most would probably be happy for some reasonable success in the main market for which they created the work. And of course, many create for the sheer pleasure of bringing new works into being, others for purposes of persuading others to their point of view, still others to express sorrow or other emotions, some because they feel they have no choice, and some because they want to get tenure or otherwise advance their careers.

The incentives-to-invest rationale for granting exclusive rights to induce authors to create is, of course, often overstated. ${ }^{16}$ This is particularly true as to the grant of derivative work rights because it gives rights holders power to inhibit the creation of follow-on works that, if allowed, would advance the progress of science.

\section{B. AUTHORS SHOULD HAVE TIME TO PLAN DERIVATIVES}

A second rationale for granting authors some derivative work rights arises from recognition of social benefits likely to flow from deferring, at least for some time, to authorial decisions about whether, when, on what terms, and how to enter derivative markets. Often authors are busy enough simply trying to finish their works and making arrangements for the works to appear in the primary market for which they were created (for example, books to be sold in bookstores or online). Authors may well want to see how their works do in this market before making decisions about entry into derivative markets and formulating strategies for how to succeed in those markets.

If authors lacked legal rights to control derivative markets (for example, had no power to stop translations into other languages or the making of sequels or prequels), some might rush to create or arrange for the creation of derivatives in order to beat unauthorized entrants into the derivative market. ${ }^{17}$ "The derivative work right thus can be defended as a tool that allows authors to take their time." 118

Allowing authors to take some time before entering derivative markets may well improve the quality of the derivatives eventually produced. ${ }^{119}$ Even when the author of an original work does not feel qualified to create the derivative herself (for example, because she does not have the language facility to do a

116. See, e.g., Julie E. Cohen, Creativity and Culture in Copyright Theory, 40 U.C. DAvIs L. Rev. 1151, 1152 (2007); Diane Leenheer Zimmerman, Copyrights as Incentives: Did We Just Imagine That?, 12 Theoretical Inquiries L. 29, 30-31 (2011); Lydia Pallas Loren, The Pope's Copyright? Aligning Incentives with Reality by Using Creative Motivation To Shape Copyright Protection, 69 LA. L. Rev. 1, 8 (2008); David A. Simon, Culture, Creativity, \& Copyright, 29 CARDozo ARTs \& ENT. L.J. 279, 281 (2011); Rebecca Tushnet, Economies of Desire: Fair Use and Marketplace Assumptions, 51 WM. \& MARY L. Rev. 513, 526-27 (2009).

117. See, e.g., Abramowicz, supra note 78, at 319-20.

118. Id. at 320 .

119. Id. at $319-20$. 
translation or the skills and equipment to make a movie of her play), she will have incentives to license well-qualified persons to prepare these derivatives. Authorized adapters also need some time to prepare satisfactory adaptations.

Among the possible socially undesirable effects of denying authors control over derivative markets would be that some might withhold the original work from the market until their own or authorized derivatives were well on their way to completion. In addition, there is reason to be concerned that unauthorized entrants would be tempted to offer close substitutes for the authors' own or authorized derivatives instead of developing their own original works. This may lead to an undesirable crowding of derivative markets for popular works because there will be "inefficiently high levels of imitation." 120 Yet, a countervailing consideration is that the derivative work right, again unless carefully limited to foreseeable markets akin to the nine definitional examples, may and often does impede competition and ongoing innovation in the development of socially beneficial derivatives.

A quandary for copyright is what to do about authors who decide not to enter derivative markets and not to license others to make certain kinds of derivatives. During his lifetime, J.D. Salinger, for instance, chose not to write a sequel to Catcher in the Rye. When Fredrik Colting wrote a book imagining the life of the main character of Catcher sixty years later, Salinger sued him for copyright infringement. Although the Court of Appeals for the Second Circuit vacated the preliminary injunction against publication of Colting's novel on procedural grounds, it expressed support for the merits of Salinger's claim that Colting's work infringed his copyright. ${ }^{121}$

This case illustrates the harms to the ongoing progress of knowledge and to free-expression interests of follow-on creators that arise when authors choose not to enter derivative markets for which there would be demand and when authors object to unauthorized entrants. Colting exemplifies the creative second comer who is willing to invest in the creation of these derivatives. To encourage subsequent authors to build upon previous works, courts should consider, in assessing fair use defenses for follow-on works such as Colting's novel, whether the author of the underlying work has prepared or authorized derivatives after passage of a considerable period of time. ${ }^{122}$ Alternatively, creative reworkings such as Colting's novel should be allowed to be marketed as long as revenues are shared with the owner of rights in the underlying work. ${ }^{123}$

120. Id. at 321.

121. Salinger v. Colting, 607 F.3d 68, 78, 83-84 (2d Cir. 2010) (vacating injunction because trial court failed to apply traditional principles of equity, but concurring that Salinger was likely to win on the merits).

122. I agree with commentators who think that fair use should become broader over time so that unauthorized works such as Colting's should be permissible. See, e.g., Joseph P. Liu, Copyright and Time: A Proposal, 101 Mich. L. Rev. 409, 461 (2002); William F. Patry \& Richard A. Posner, Fair Use and Statutory Reform in the Wake of Eldred, 92 CALIF. L. REv. 1639, 1643 (2004).

123. Some commentators suggest that second comers should be allowed to prepare derivatives as long as they pay a fair share of revenues generated from these works to the owners of rights in the 


\section{UNJUST ENRICHMENT CONSIDERATIONS}

When William Butler Yeats wrote the poem "The Second Coming," he could not have expected that it would become the lyrics of a song entitled "Slouching Toward Bethlehem" written by Joni Mitchell or that Mitchell would make a sound recording of the song with his poem as its lyrics. Poetry is not a particularly lucrative field to begin with, and poets may, in general, be among those who create primarily to express themselves. There are typically few derivative markets for poets to exploit, although song lyrics are more plausible derivative uses of poems than sculptures, motion pictures, or choreography.

Even if Yeats created this poem with no expectation of a right to control derivative markets, Mitchell's commercial exploitation of the poem through public performances of her song and sales of sound recordings without Yeats's permission (assuming the poem was in copyright) ${ }^{124}$ might seem an unjust enrichment. ${ }^{125}$ If Mitchell has collected significant sums of money from her own and others' performances of the song and from recordings, the commercial value of these exploitations was not due solely to her creative efforts. Yeats's poem is, after all, an important component of the value of the song, whether performed or recorded. Should not Yeats and his heirs be entitled to share in this wealth (again assuming the work in question is in copyright)?

There are many authors who create valuable literary or artistic works without realizing the possibility that derivative markets might exist for their creations, let alone being motivated to create by the prospect of lucrative derivative markets that might be available for their works. A child prodigy might compose music, an unschooled primitive artist may paint, a prisoner may write short stories while taking a creative-writing course, a patient in a hospital might take up drawing as part of her recuperation, or an amateur photographer in a rural area might take portraits of farmers that win critical praise. Should the ignorance of these creators about copyright or an initial lack of commercial motive make these authors' creations vulnerable to appropriation by any entrepreneurial second comer who sees commercial value in a derivative market? Should motion-picture studios and others who foresee and regularly mine derivative

underlying works. See, e.g., Paul Edward Geller, Hiroshige vs. Van Gogh: Resolving the Dilemma of Copyright Scope in Remedying Infringement, 46 J. CoPYRIGHT Soc'Y USA 39, 65 (1998); Jed Rubenfeld, Freedom of Imagination: Copyright's Constitutionality, 112 YALE L.J. 1, 56-57 (2002).

124. This poem, first published in 1920, is now in the public domain both in Ireland and in the United States, although it was not in the public domain in Ireland when Mitchell composed her song in 1991.

125. Unjust enrichment as a rationale for protecting the interests of creators who use preexisting works when making new works has been analyzed in Gordon, supra note 108. Professor Gordon focused on common law decisions giving expansive intellectual property rights in information which "eager[ly] accept[ed] the voracious notion that beneficial products of human effort ... should yield court-protected rewards for the persons who create them." Id. at 151 . Such expansive rulings, she thought, "threaten to chill more creativity than they induce, and they may impair our culture's ability to respond flexibly to future opportunities and dangers." Id. at 157 . Though defendants in these cases were free riding to some extent on the creations of others, they were not "mere parasites" but often creators themselves who contributed new works. Id. 
markets be the only copyright owners who enjoy derivative work rights? ${ }^{126}$

Congress seems to have decided that all authors of protected works and not just the perspicacious ones should enjoy some derivative work rights in order to avoid unjustly enriching those who would otherwise be tempted to appropriate expression from other authors' works without permission and exploit this expression in derivative markets. ${ }^{127}$ However, this rationale does not justify giving an expansive interpretation to the derivative work right. The interests of competition and ongoing innovation as well as the free-expression interests of subsequent authors must be given due weight and not be automatically trumped by unbounded unjust-enrichment claims.

Prospective makers of derivative works cannot know the subjective derivative work expectations of any particular author or what markets this author did or did not foresee when creating his or her works, but they can know objectively that they should ask permission when interested in creating one or more of the nine exemplary derivatives and close analogues to those set forth in the statutory definition. Narrowing the derivative work right in this way is consistent with the text of the statute and the constitutional purpose of copyright law. Unjust enrichment as a rationale for derivative work rights should, therefore, be tethered to markets that are reasonably foreseeable for works of that kind.

\section{Derivative Uses that Are Not Within the Derivative Work Right}

Thus far, this Article has focused attention on the legislative evolution of

126. Professor Gordon was rightly concerned that a broad rule against reaping without sowing in the intellectual property field would overemphasize the interest of the first creator and undervalue the interests of follow-on creators. She looked to the law of unjust enrichment for principles that might balance the interests of initial and follow-on creators of information-rich works. Id. at 164-65. This led her to suggest that "the plaintiff [in such cases should have to] prove it is foreseeable that this defendant could be within the range of the plaintiff's customers, or that this defendant intends to sell to such customers." Id. at 189 n.154. Foreseeability may be a sound constraint on the reach of common law intellectual property rights (for example, trade secrets). However, if the legislature has decided to accord authors certain rights to control derivatives, these derivative rights should be available to all, not just those who foresaw the possibility of derivative markets. See section V.D for reasons that courts should take foreseeability into account when faced with novel derivative work claims. The section of the Restatement (Third) of Restitution and Unjust Enrichment entitled "Interference with Intellectual Property and Similar Rights" also states:

The rule of this section depends on a body of law that defines the underlying entitlements ....

There is no unjust enrichment . . unless the defendant has obtained a benefit in violation of the claimant's right to exclude others from the interests in question. The contours of such underlying rights (if any) must therefore be decided before it can be asserted that the defendant has committed any misappropriation or infringement.

RESTATEMENT (ThIRD) OF RESTITUTION \& UNJUST ENRICHMENT $\$ 42 \mathrm{cmt}$. b (2011).

127. The derivative work right, like most other copyright rules, applies to every author and her works. See 17 U.S.C. $\S 103$ (2006). It does not matter whether an author wants or is indifferent to copyright protection-rights attach automatically and last for seventy years past the author's death, even if she recouped the creation investment many times over in the first ten years of the copyright term. See id. $\$ 302$. 
the derivative work right, the role that the nine exemplary derivatives play in clarifying the scope of this right, and justifications for the right, all of which support a reasonable but nevertheless limited scope for it. This Part considers numerous statutory provisions and doctrines of U.S. copyright law that limit the scope of the derivative work right. Section A considers a statutory limit on authorial control over the manufacture of useful articles first depicted in copyrighted works. This rule fosters competition and ongoing innovation in the useful arts. Exclusive rights to make such items may be available from patent law but not from copyright law. Section B discusses several other specific exceptions that directly or indirectly limit the reach of the derivative work right. These rules promote autonomy interests of consumers, free-expression interests of subsequent authors, and competition policy interests of the public. Section C explores the implications of a failed copyright-industry proposal to extend derivative work rights to include the preparation of supplementary works. This proposal would have interfered with the free-expression interests of subsequent authors and with the interests of consumers in competition among works that draw upon other works without appropriating and unfairly transforming the works' expression.

Sections D through $\mathrm{F}$ consider several court decisions holding that reference works, interoperable and add-on software, and web-based uses such as framing, linking, and pop-up ads lie outside the derivative work right. These decisions have heavily relied upon copyright rules that allow second comers to reuse facts, methods of operation, and functional-design elements embodied in protected works. ${ }^{128}$ These rulings, which narrow the scope of the derivative work right, have promoted competition and ongoing innovation, free-expression interests of follow-on creators, and autonomy interests of users of copyrighted works.

\section{A. USEFUL ARTICLES ARE NOT DERIVATIVE WORKS}

An important statutory limit on the scope of the derivative work right is the exclusion from copyright protection of designs of useful articles (for example, chairs, bicycles, clothing) depicted in copyrighted works. ${ }^{129}$ Manufacture of such articles is typically based upon a design first embodied in a drawing and the articles are adaptations of the drawn design, but they are not infringing derivative works. This rule is a logical extension of the Supreme Court's 1880 decision in Baker v. Selden. ${ }^{130}$ Selden alleged infringement because the columns and headings of the bookkeeping forms in Baker's book were substantially similar to those in Selden's book. The Court agreed with Selden that the forms were very similar but ruled that the copyright in Selden's book extended only to his explanation of the bookkeeping system but not to the bookkeeping system 
itself. ${ }^{131}$ Because Selden's forms were an implementation of this system, not an explanation of it, Baker's derivative use of the forms did not infringe Selden's copyright. ${ }^{132}$

Dozens of cases have followed the ruling in Baker, including one in which a second comer made dresses that looked like those depicted in a copyrighted drawing. ${ }^{133}$ One prominent commentator criticized this noninfringement ruling as "illogical" because the dresses depicted in the drawings were, in his view, infringing derivative works. ${ }^{134}$

The dress-design ruling is, however, logical in light of Baker and decades of decisions holding that the designs of useful articles depicted in copyrighted works are outside the scope of copyright protection. ${ }^{135}$ This principle was incorporated into the 1976 Act through a provision that codifies holdings of Baker and its progeny that copyrights in drawings of useful designs do not extend to the useful designs depicted therein. ${ }^{136}$ Competition and innovation are more likely to thrive if copyright law protects only the way that authors express themselves in words about or illustrations of the designs of useful articles. Legal protection for innovative designs of useful articles has been left to the rigors of the patent system. ${ }^{137}$

\section{B. SOME DERIVATIVE USES ARE PRIVILEGED}

Several provisions of U.S. copyright law expressly allow users to make unauthorized adaptations to their copies of copyrighted works in order to protect the autonomy, personal property, and sometimes the privacy interests of consumers. Owners of copies of computer programs have the right, for instance, to adapt the software to make it more useful for their purposes; they can also authorize third parties to make adaptations on their behalf. ${ }^{138}$ This includes the right to fix bugs that are causing the program to execute improperly, to integrate the software with other programs, and to customize the programs to meet the users' particular needs. ${ }^{139}$ This privilege is not, however, so broad that firms can

131. Id. at 102 .

132. Id. at 107.

133. Jack Adelman, Inc. v. Sonners \& Gordon, Inc., 112 F. Supp. 187, 188 (S.D.N.Y. 1934).

134. Goldstein, supra note 82, at 229-31. This view was criticized in Ralph S. Brown, The Widening Gyre: Are Derivative Works Getting Out of Hand?, 3 CARDOzo ARTs \& ENT. L.J. 1, 3, 8 (1984) (arguing that the derivative work right should not go to the "forbidden area" by protecting useful articles depicted in copyrighted works).

135. In another article, I discussed these decisions and rationales for denying protection to useful designs depicted in copyrighted works at length. See generally Pamela Samuelson, Why Copyright Law Excludes Systems and Processes from the Scope of Its Protection, 85 Tex. L. Rev. 1921 (2007).

136. 17 U.S.C. § 113(b) (2006).

137. See, e.g., Pamela Samuelson, Baker v. Selden: Sharpening the Distinction Between Authorship and Invention, in Intellectual. Property Stories 159, 172-88 (Jane C. Ginsburg \& Rochelle Cooper Dreyfuss eds., 2006).

138. See 17 U.S.C. § $117(\mathrm{a})(1)$.

139. See, e.g., Foresight Res. Corp. v. Pfortmiller, 719 F. Supp. 1006, 1009-10 (D. Kan. 1989) (holding that an enhancement of software for in-house use was noninfringing under $\S 117(\mathrm{a})$ ). See 
make a regular business out of reselling unauthorized adaptations to or adaptation services for other firms' proprietary software. ${ }^{140}$

Another adaptation right allows programmers to develop and distribute software designed to temporarily alter the play of DVD movies by making parts imperceptible during private performances of the works in viewers' homes. ${ }^{141}$ Some entrepreneurial software developers recognized the potential market for family-friendly DVD movies so that viewers could enjoy the movies without encountering scenes or language in the original that would be offensive to them. ${ }^{142}$ Although developing software to mute foul language and bypass scenes of sex and violence might well have been noninfringing under certain precedents had the lawsuit against its maker proceeded to judgment, ${ }^{143}$ motionpicture studios claimed that this software was designed to enable infringement of the derivative work right. ${ }^{144}$ Members of Congress agreed that this type of recasting of the expression in motion pictures should be lawful. ${ }^{145}$ This software created a new market for this product and may well have expanded the market for the movies to include consumers who had been reluctant to buy the movies because of offensive material that could now be excised at the consumers' will.

Consumer autonomy and real property interests are protected by a statutory privilege to alter architectural works one owns. ${ }^{146}$ Homeowners are free to remodel or renovate their homes (for example, by adding a new bathroom, bedroom, or deck). Owners of office buildings can similarly rearrange the internal spaces to add new cubicle spaces or conference rooms. ${ }^{147}$ Taking photographs or drawing pictures of publicly visible architectural works is similarly privileged, thereby protecting the autonomy and free-expression interests of subse-

generally Pamela Samuelson, Modifying Copyrighted Software: Adjusting Copyright Doctrine To Accommodate a Technology, 28 JURIMETRICS J. 179 (1988).

140. See, e.g., Allen-Myland, Inc. v. Int'l Bus. Machs. Corp., 746 F. Supp. 520,537 (E.D. Pa. 1990) (holding that a service that routinely adapted IBM programs for lessees of IBM equipment infringed).

141. 17 U.S.C. $\$ 110(11)$; see also id. $\$ 115$ (permitting a compulsory licensee a limited right to adapt a copyrighted musical work in the course of preparing a privileged cover recording).

142. See Clean Flicks of Colo., LLC v. Soderbergh, 433 F. Supp. 2d 1236, 1240 (D. Colo. 2006). Clean Flicks and other companies sought a declaratory judgment that their products were noninfringing. After Congress enacted the privilege for this type of filtering software, producers of the software such as ClearPlay were excused from the suit, whereas Clean Flicks and other companies that sold edited films were held infringers of the movie studios' reproduction and distribution rights. See infra notes $237-40$ and accompanying text for further discussion of these cases.

143. See, e.g., Lewis Galoob Toys, Inc. v. Nintendo of Am., Inc., 964 F.2d 965, 968 (9th Cir. 1992) (holding that software that temporarily changed the play of Nintendo videogames did not infringe the derivative work right). As in Galoob, ClearPlay did not incorporate any expression from the DVD movies in making software that muted or bypassed objectionable content. The software only temporarily altered the play of these movies, and the software was programmable by users. Galoob is discussed infra notes 188-95 and accompanying text.

144. Clean Flicks, 433 F. Supp. $2 d$ at 1239.

145. Family Movie Act of 2005, Pub. L. No. 109-9, § 202, 119 Stat. 218, 223-24 (codified as amended at 17 U.S.C. $\S 110$ (2006)); see H.R. REP. No. 109-33(1), at 5-7 (2005), reprinted in 2005 U.S.C.C.A.N. 220, 224-26.

146. 17 U.S.C. $\$ 120$ (b).

147. Owners of protected architectural works are also entitled to destroy them. Id. 
quent creators. $^{148}$

Copyright's exhaustion-of-rights doctrine, which recognizes that owners of copies of protected works have personal-property rights entitling them to resell or otherwise dispose of their copies, has been recognized as providing these owners with some rights to modify their copies. ${ }^{149}$ Scribbling in the margins of a book, for instance, does not infringe the derivative work right. ${ }^{150}$ The purchaser of a copyright-protected hobbyhorse has been held to be entitled to repaint and resell it. ${ }^{151}$ Similarly lawful was the transformation of copyrighted fabric into bedsheets. ${ }^{152}$ Owners of copies also have the right to recondition, bind or rebind, and otherwise repair their copies of copyrighted works. ${ }^{153}$ However, exhaustion rights are more limited for visual art. ${ }^{154}$

The autonomy and free-expression interests of creative reusers of incopyright works as well as the public's interest in access to creative reworkings

148. Id. § 120(a).

149. The statutory exhaustion-of-rights provision, 17 U.S.C. $\& 109$ (a), limits only the right to control the distribution of copies of protected works, not the derivative work right. However, common law exhaustion principles go beyond this. See, e.g., ARTHUR W. WeIL, AMERICAN Copyright Law 444 (1917) ("The law is well settled that the owner of a copy of a copyrighted work may make such physical use of it, as a physical object, as he pleases."); Aaron Perzanowski \& Jason Schultz, Digital Exhaustion, 58 UCLA L. Rev. 889, 932 (2011). Section 109(a) provides the owner of a copy with the right to "dispose" of it as he or she chooses. See, e.g., H.R. REP. No. 94-1476, at 79 (1976) (indicating this includes the right to destroy a copy). Modifying one's copy may be a nonresale form of disposition, perhaps a lesser included right to the right to destroy it. But see infra section V.B for a discussion of a Ninth Circuit ruling that did not accept this principle.

150. NimMER \& NimMER, supra note $25, \S 8.12[\mathrm{~B}][1][\mathrm{d}][\mathrm{i}][\mathrm{III}]$. Some types of copyrighted works invite derivative uses. Coloring books, for example, provide owners of copies with an opportunity to use paints or crayons to fill in the blanks of drawings with colors of the purchasers' choosing. Crossword-puzzle books invite users to fill in the blanks of words based on clues provided by the books' authors. Some software programs are designed to provide purchasers with images they can use in presentations, thereby inviting users to make derivative uses of those images.

151. See Blazon, Inc. v. DeLuxe Game Corp., 268 F. Supp. 416, 429-30 (S.D.N.Y. 1965).

152. See Precious Moments, Inc. v. La Infantil, Inc., 971 F. Supp. 66, 69 (D.P.R. 1997).

153. See, e.g., Fawcett Publ'ns v. Elliot Publ'g Co., 46 F. Supp. 717 (S.D.N.Y. 1942) (holding that rebinding and combining sets of comic books was not infringement); Bureau of Nat'l Literature $v$. Sells, 211 F. 379, 381-82 (W.D. Wash. 1914) (holding that overhauling and reconstructing second-hand sets of copyrighted books was not infringement). But see Nat'l Geographic Soc'y v. Classified Geographic, Inc., 27 F. Supp. 655, 660 (D. Mass. 1939) (holding that selling books that compiled articles from National Geographic Magazine on specific subjects (for example, birds) infringed, although the court did not say which exclusive right was infringed).

154. Certain works of visual art are now protected by the Visual Artists Rights Act of 1990 (VARA) from "any intentional distortion, mutilation or other modification ... that would be prejudicial to [the author's] honor or reputation" as well as from destruction if the work is of recognized stature. 17 U.S.C. $\S 106 \mathrm{~A}(\mathrm{a})(3)$. This right is confined in several ways. For example, fair use limits VARA's scope, which means that some critical or playful adaptations to visual artworks may be exempt even if the artist/author considers the adaptations to be offensive. Id. $\$ 106 \mathrm{~A}($ a). Also privileged are modifications that are the "result of the passage of time or the inherent nature of the materials," conservation efforts, or public presentation of the work, such as by placement and lighting. Id. $\S 106 \mathrm{~A}(\mathrm{c})$. VARA also does not apply to modifications of art reproductions of VARA-protected visual art (for example, a poster of a painting). Amy Adler has pointed out that contemporary art often embraces creative destruction or modification of art as a way to give works new meaning. See Amy Adler, Against Moral Rights, 97 CaLIF. L. Rev. 263, 280-87 (2008). 
are often enabled by copyright's fair use doctrine. This statutory limitation on the derivative work right calls for consideration of the purpose of a second comer's use, the nature of the protected work, the amount appropriated, and the potential harm to the market. ${ }^{155}$ An illustrative case is Campbell v. AcuffRose Music, Inc. ${ }^{156}$ The copyright owner of the Roy Orbison song "Oh, Pretty Woman" sued Campbell and other 2 Live Crew rappers for infringing the derivative work right with their song about a "big hairy woman." Campbell argued that the 2 Live Crew song was a parody of "Oh, Pretty Woman" that qualified as fair use because it was a form of critical commentary on the earlier song. ${ }^{157}$

Parody, by definition, is based upon the preexisting work that it mocks or criticizes; of necessity, it recasts expression from the original in order to comment on it. Parody can, moreover, only be effective if qualitatively substantial amounts of expression are taken from the earlier work. ${ }^{158}$ In reversing a ruling in favor of Acuff-Rose, the Court emphasized that the key issue is whether the amount taken from the original work is reasonable in light of the parodist's purpose. ${ }^{159}$ As for market harm, the Court noted that "a lethal parody, like a scathing theatre review, [might] kill[] demand for the original," but this "does not produce a harm cognizable under the Copyright Act." 160 Campbell also recognized that copyright owners may be more interested in suppressing parody and critical commentary than in licensing it, giving rise to market failure. ${ }^{161}$ Since the Campbell decision, the transformativeness (or not) of a challenged use has become an important factor weighing in favor of fair use determinations, perhaps even the most important factor. ${ }^{162}$ Fair use is an important rule protecting the free-expression interests of follow-on creators and the public's interest in access to their works by narrowing the scope of the derivative work right.

The free-expression interests of recording artists and performers, consumer interests in new renditions of music, and competition in the sound recording

155. 17 U.S.C. § 107; see, e.g., Pamela Samuelson, Unbundling Fair Uses, 77 Fordham L. Rev. 2537, 2546-80 (2009) (discussing fair use cases involving free expression, free speech, and other authorial interests).

156. 510 U.S. 569 (1994).

157. $l d$. at $580-81$.

158. Id. at 588. ("Parody's humor, or in any event its comment, necessarily springs from recognizable allusion to its object through distorted imitation.")

159. Id.

160. Id. at 591-92. The challenge "is to distinguish between "[b]iting criticism [that merely] suppresses demand [and] copyright infringement[, which] usurps it."' Id. at 592 (alterations in original) (quoting Fisher v. Dees, 794 F.2d 432, 438 (9th Cir. 1986)).

161. Id.; see also Robert P. Merges, Are You Making Fun of Me?: Notes on Market Failure and the Parody Defense in Copyright, 21 AIPLA Q.J. 305, 308 (1993).

162. Transformation has a surprisingly positive valence in fair use cases, although it has a negative valence when the derivative work right is alleged to be infringed. For an insightful analysis of this conundrum, see for example, Reese, supra note 89, at 467-68, 476, 484-85 (pointing out that a transformative purpose is the focus of fair use analysis and transformation of expression is the focus of a derivative work right inquiry). 
industry are well served by some statutory limitations on the exclusive rights of sound-recording copyright owners. ${ }^{163}$ Anyone is free, for instance, to imitate or simulate the performance embedded in recorded music because sound-recording copyrights can only be infringed by reuse of the actual recorded sounds. ${ }^{164}$

The derivative work right is thus limited by numerous provisions of the 1976 Act in order to protect interests of second comers and of the public in competition and ongoing innovation, in making reasonable uses of purchased copies, and in making new works that creatively repurpose expression from the works on which they are based.

\section{SUPPLEMENTARY WORKS ARE NOT DERIVATIVE WORKS}

Sections A and B discussed numerous ways that Congress expressly limited the derivative work right. This section considers the implications of the nonadoption of a proposal made by several copyright-industry associations during the copyright revision process to amend the derivative work right so that it would extend to controlling the preparation of supplementary works. ${ }^{165}$ Proponents would have defined "supplementary work" as:

[A] work prepared for publication as a secondary adjunct to a work by another author for the purpose of introducing, concluding, illustrating, explaining, revising, commenting upon or assisting in the use of the other work, such as forewords, introductions, prefaces, prologues, epilogues, [pictorial] illustrations, musical arrangements, maps, charts, tables, editorial notes, tests, [and] answer[s] material for tests, bibliographers, appendixes, and indexes. ${ }^{166}$

The publisher proponents were particularly interested in getting control over the manufacture and sale of answer sheets for tests. ${ }^{167} \mathrm{Had}$ that proposal been

163. See 17 U.S.C. §114(a)-(c) (2006) (limiting reproduction, derivative work, and publicperformance rights as applied to sound recordings). Public performances of the music do need to be licensed. But a compulsory-license regime governs sound recordings of protected music. See id. $\S 115$.

164. Id. $\$ 114(\mathrm{~b})$. A recording artist who samples from prior sound recordings and melds them into another recording may, however, be sued. See, e.g., Bridgeport Music, Inc. v. Dimension Films, 410 F.3d 792, 801 (6th Cir. 2005) (holding reuse of a sample in a subsequent recording was not a de minimis use). Numerous commentators have argued that artists should have greater creative freedom to sample. See, e.g., McLEOD \& DiCola, supra note 92, at 240-47.

165. See Copyright Law Revision: Hearings on H.R. 4347, H.R. 5680, H.R. 6831, and H.R. 6835 Before Subcomm. No. 3 of the H. Comm. on the Judiciary, 89th Cong. 134 (1966) (memorandum of American Book Publishers Council, Inc. et al. proposing that "and supplementary" be inserted after "derivative" in $\S 106$ and proposing a definition of "supplementary work"). The memorandum was adopted by a coalition of copyright-industry groups on April 6, 1965.

166. Id. (alterations in original). The publishers did persuade Congress to designate supplementary works as among the specially commissioned works eligible for treatment as works made for hire. See 17 U.S.C. $\$ 101$ (2) (defining "work made for hire").

167. See House Comm. on the Judiciary, 88th Cong., Copyright law Revision Part 4: Further Discussions and Comments on Preliminary Draft for Revised U.S. Copyright Law 302 (Comm. Print 1964) (comments of American Textbook Publishers Institute, July 17, 1964, stating, "An important part of the publishers' income is derived from the annual sale of answer sheets. To the extent that these 
adopted, it would have vastly expanded the reach of derivative-use rights and hindered considerably the ability of second comers to create and disseminate new works, impeding fulfillment of the constitutional purpose of copyright.

Leaving aside musical arrangements (which today's derivative work right explicitly covers), the exemplary types of supplementary works in the proposed definition do and should lie outside the reach of the derivative work right. Under Baker and its progeny, for example, blank-test answer sheets should be as unprotectable as Selden's bookkeeping forms were. ${ }^{168}$ Explanations, commentaries, prefaces, and the like may be "based upon" the works to which they refer in the loose sense of this term, but not in a manner that falls within the derivative work right. This is because these types of works are typically independently created original texts that do not generally appropriate expression from the works on which they comment or otherwise unfairly free ride on the works they discuss. ${ }^{169}$ Works such as indexes and bibliographies provide information about works; they do not appropriate the expression of works to which they point. It would thwart the constitutional goal of promoting the ongoing progress of knowledge to restrict the opportunity to create such works to owners of rights in the works being explained, commented upon, or indexed. Maps, charts, and tables that depict or illustrate facts from protected works should likewise not be wholly under the control of the author of the works from which they draw information. ${ }^{170}$ It is important to the progress of knowledge that second comers are able to reuse data from prior works to reinterpret them and proffer alternative representations.

Not only did the supplementary work right proposal fail to be adopted, but it seems to have prompted the Register of Copyrights to cast doubt on the proposition that such things as "indexes, tests, answers to tests, study guides, work sheets, etc." were within the scope of protection that copyright owners should enjoy. ${ }^{171}$ The Register also insisted that the derivative work right should

answer sheets are pirated-freely copied without recompense to the publisher-the publisher is deprived of necessary income for further research and development.").

168. The unprotectability of blank forms is a well-established rule of U.S. copyright law. See, e.g., Taylor Instrument Cos. v. Fawley-Brost Co., 139 F.2d 98, 100 (7th Cir. 1943) (holding forms for recording temperatures unprotectable by copyright law under Baker).

169. Preparing an index to another author's work does not infringe copyright. See, e.g., N.Y. Times Co. v. Roxbury Data Interface, Inc., 434 F. Supp. 217 (D.N.J. 1977) (holding an index to New York Times indexes to be noninfringing).

170. U.S. copyright law is consistent with the First Amendment because facts and ideas are not within the scope of copyright's protections. See, e.g., Eldred v. Ashcroft, 537 U.S. 186, 219-20 (2003).

171. Instead of endorsing the broad language proposed by these industry groups, the Register stated:

Close questions can arise as to whether the preparation of material such as indexes, tests, answers to tests, study guides, work sheets, etc., constitutes an infringement of the work to which they are related. In some cases the dependence on the copyrighted source may be so great as to constitute infringement, and in others the only things taken may be uncopyrightable elements such as ideas or isolated facts.

House Comm. on the Judiciary, 89Th Cong., Copyright Law Revision Part 6: Supplementary Report of the Register of Copyrights on the General Revision of the U.S. Copyright LaW: 1965 Revision BIL. 
not be infringed unless the second work had appropriated a substantial amount of expression from the first work. ${ }^{172}$ Unless supplementary works satisfy this norm, which they rarely will, they should be considered to be outside the scope of the derivative work right.

\section{CONCORDANCES AND SIMILAR REFERENCE WORKS ARE NOT DERIVATIVE WORKS}

Concordances are among the many types of reference works that, by their nature, are based upon one or more preexisting works in a loose sense of that term. ${ }^{173}$ Perhaps because of the substantial independent effort generally required to make concordances and similar reference works, there has rarely been a legal challenge to the preparation of such works. However, author J.K. Rowling asserted that the unauthorized publication of a reference book with details about characters, spells, events, and settings of her Harry Potter novels should be treated as an unlawful derivative work in Warner Brothers Entertainment, Inc. v. RDR Books. ${ }^{174}$ Rowling claimed that she planned to create an encyclopedia similar to RDR's Harry Potter Lexicon and that RDR's book would undermine the market for this planned derivative. ${ }^{175}$

The court pointed out that a reference work such as the Lexicon was dissimilar to the nine exemplary derivatives in the statutory definition. Moreover, "[b]y condensing, synthesizing, and reorganizing the preexisting material in an $\mathrm{A}-$ to- $\mathrm{Z}$ reference guide, the Lexicon does not recast the material into another medium to retell the story of Harry Potter, but instead gives the copyrighted material another purpose." ${ }^{176}$ The Lexicon was, therefore, not an infringing derivative work of the novels, and "competing with Rowling's planned encyclopedia [was] therefore permissible." 177 The court was not impressed by Rowling's intent to publish a similar encyclopedia, saying that "the market for reference guides to the Harry Potter works is not exclusively hers to exploit or license, no matter the commercial success attributable to the popularity of the original works." ${ }^{" 178}$ The Harry Potter books are, of course, fictional

18 (Comm. Print 1965). When considered as a response to the supplementary work right proposal, this part of the Register's Report seems a reproach.

172. Id.

173. A "concordance" is "an alphabetical index of the principal words in a book or the works of an author with their immediate contexts." MerRIAM-WeBSTER's ColleGIATE Dictionary (11th ed. 2004). Thus, by definition, concordances are based upon preexisting works and draw substantial materials from them. See, e.g., Warner Bros. Entm't Inc. v. RDR Books, 575 F. Supp. 2d 513, 538 n. 17 (S.D.N.Y. 2008) (citing Well-Made Toy Mfg. Corp. v. Goffa Int'l Corp., 354 F.3d 112, 117 (2d Cir. 2003)) ("A work is not derivative . . simply because it is 'based upon' the preexisting works.").

174. 575 F. Supp. 2d at 525-33.

175. Id. at $549-50$.

176. Id. at 539 .

177. Id. at 550 .

178. Id. The court recognized that "[t]o fulfill its purpose as a reference guide to the Harry Potter works, it is reasonably necessary for the Lexicon to make considerable use of the original works." Id. at 546. The Lexicon litigation settled after RDR agreed to make changes to certain parts of the Lexicon. See id. at 547-49 (giving examples of verbatim copying and close paraphrasing); Rowling v. RDR 
works, but a reference work about specific details in the books such as spells and incantations is a nonfiction work that does not recast Rowling's original expression in a manner that produces copyright harm. Facts about fictional details are still facts, and facts are not protected by copyright law. ${ }^{179}$ To limit the right to prepare reference works to the authors of the underlying works would interfere with the ongoing progress of knowledge and the free-expression interests of authors and publishers of such works. It would deprive the public of the benefits of competition and access to a new product quite different from the product that the author of the referred works might make.

\section{E. INTEROPERABLE AND ADD-ON SOFTWARE ARE NOT DERIVATIVE WORKS}

Many software developers design their products to interoperate with existing programs; they must necessarily conform their programs with the interface specifications established by the other programs and must incorporate those specifications in their software. Interface specifications provide precise details about how a second program must send and be prepared to receive information so that the second program can invoke the first program's services. ${ }^{180}$ The design of program interfaces requires considerable creativity, skill, and judgment and is certainly part of the "structure, sequence, and organization" of computer programs. ${ }^{181}$

For almost a decade, reimplementing program interfaces without a license seemed legally risky. ${ }^{182}$ Some believed that unlicensed developers of software capable of interoperating with another program were infringers of the derivative work right because the second program was based upon the preexisting program and arguably recast the first program's functional expression. ${ }^{183}$

Books, Citizen MeDIA LAw ProjeCt (Dec. 7, 2007), http://www.citmedialaw.org/threats/rowling-v-rdrbooks (discussing the settlement).

179. Feist Publ'ns, Inc. v. Rural Tel. Serv. Co., 499 U.S. 340, 347-48 (1991). Although Feist stated that facts are unprotectable because they are discovered, not created, id., it seems unlikely that the Court meant to put biographers, historians, and other nonfiction authors at risk of running afoul of copyright for drawing facts about fiction from their subjects' works. See, e.g., Justin Hughes, Created Facts and the Flawed Ontology of Copyright Law, 83 Notre Dame L. REv. 43,47 (2007). Unfortunately, at least one case has taken the opposite view. See infra notes 290-95 and accompanying text.

180. See, e.g., Pamela Samuelson, Are Patents on Interfaces Impeding Interoperability?, 93 MinN. L. Rev. 1943, 1946-54 (2009) (explaining interfaces and interoperability).

181. Id. at 1955-58; see, e.g., Whelan Assocs. v. Jaslow Dental Labs., Inc., 797 F.2d 1222, 1234-45 (3d Cir. 1986) (ruling that the structure, sequence, and organization (SSO) of programs was protectable by copyright law).

182. One early case rejected a software compatibility defense. See Apple Computer, Inc. v. Franklin Computer Corp., 714 F.2d 1240 (3d Cir. 1983). Not until Computer Associates International v. Altai, Inc., 982 F.2d 693 (2d Cir. 1992), was there a court ruling that elements of programs necessary to interoperability were beyond the scope of copyright protection. See, e.g., Pamela Samuelson, The Past, Present and Future of Software Copyright: Interoperability Rules in the European Union and United States, 2012 EUR. INTELL. Prop. Rev. 229, 232-33 (2012) (relating this history).

183. See, e.g., Reply Brief for Plaintiff-Appellant, Computer Assocs. Int'l, Inc. v. Altai, Inc., 982 F.2d 693 (2d Cir. 1992) (No. 91-7893), 1991 WL 11010234 (relying on Whelan and arguing that interfaces were within copyright's scope). 
Courts ultimately decided that program interfaces were unprotectable elements of computer programs as the functional requirements for achieving interoperability. ${ }^{184}$ Important to those rulings was a statutory provision indicating that methods of operation and procedures are not within the scope of protection that copyright provides to protected works. ${ }^{185}$ The command hierarchy of a popular spreadsheet program was similarly held to be an unprotectable method of operation. ${ }^{186}$ By excluding these unquestionably creative elements of programs from the scope of copyright protection, the courts enabled competition and follow-on innovation in the software industry and averted the risk that the derivative work right would impede this innovation.

Even after the interoperability rulings, it was not completely obvious that courts would decide that add-on software was beyond the reach of the derivative work right. Add-on programs are targeted toward specific software and recast some functionality of that software; they are typically made by independent software companies who recognize the market potential for a new product to enhance the performance of another firm's software. ${ }^{187}$ Add-on software complements the software on which it runs, but usually it cannot be run independently.

The legality of add-on software was tested in Lewis Galoob Toys, Inc. v. Nintendo of America, Inc. ${ }^{188}$ Galoob sold Game Genie software which allowed consumers to change certain facets of the play of Nintendo videogames (for example, extending the number of lives of a particular character). Nintendo claimed that the Game Genie infringed the derivative work right because it altered the play of games designed to run on the Nintendo platform. ${ }^{189}$ Several factors contributed to the Ninth Circuit's rejection of Nintendo's claim. For one thing, the Game Genie was useless unless the consumer had already purchased Nintendo games, so there was no risk that the Game Genie would harm sales of the Nintendo games. ${ }^{190}$ If anything, the Game Genie made Nintendo games more desirable because it enhanced the users' experiences with the games.

184. The principal case is Computer Associates International v. Altai, Inc., 982 F.2d 693 (2d Cir. 1992).

185. 17 U.S.C. § 102(b) (2006); see, e.g., Sega Enters. Ltd. v. Accolade, Inc., 977 F.2d 1510, 1526 (9th Cir. 1992) (excluding program interfaces from copyright protection under $\S 102(b)$ ).

186. See Lotus Dev. Corp. v. Borland Int'1, Inc., 49 F.3d 807, 815 (1st Cir. 1995).

187. See, e.g., Edward G. Black \& Michael H. Page, Add-On Infringements: When Computer Add-Ons and Peripherals Should (and Should Not) Be Considered Infringing Derivative Works Under Lewis Galoob Toys, Inc. v. Nintendo of America, Inc., and Other Recent Decisions, 15 Hastings Comm. \& ENT. L.J. 615, 617 (1993). Ruling for Nintendo would have been inconsistent with Altai. Id. at 622.

188. 964 F.2d 965 (9th Cir. 1992).

189. For a discussion about why interactive digital works should generally be free of derivative work claims, see, for example, Lydia Pallas Loren, The Changing Nature of Derivative Works in the Face of New Technologies, 4 J. Small \& Emerging Bus. L. 57, 76-90 (2000).

190. Galoob, 964 F.2d at 969. Nintendo relied heavily on Midway Manufacturing Co. v. Artic International, Inc. 704 F.2d 1009 (7th Cir. 1983) (holding that chips to speed up the play of Midway's videogames infringed the derivative work right). See Galoob, 964 F.2d at 968. Midway is discussed infra notes 211-15 and accompanying text. 
Unlike the nine exemplary derivatives, the Game Genie did not incorporate any expressive parts of the Nintendo games into its software. ${ }^{191}$ Nor did the Game Genie permanently change the play of the games; it only intercepted certain signals emitted by the Nintendo games and substituted other signals for them at the behest of users who valued playing the games somewhat differently than Nintendo contemplated. ${ }^{192}$ Nintendo may have wanted to get licensing revenues from makers of complementary software products, such as the Game Genie, or reserve the market for complements to itself, but that did not mean that the game developer was entitled to exclude unlicensed developers from the market for complements. ${ }^{193}$ The court construed the last clause of the derivative work right definition narrowly, deciding that the challenged work "must incorporate a protected work in some concrete or permanent 'form." 194 Because the Game Genie did not incorporate the Nintendo programs, it did not infringe the derivative work right.

Had the Ninth Circuit upheld Nintendo's claim, it would have jeopardized the considerable market for add-on software, and this would have hurt competition and innovation in the software industry and deprived consumers of new software products that enhanced the performance of other software they might own. ${ }^{195}$

\section{F. VARIOUS ONLINE ACTIVITIES DO NOT CREATE DERIVATIVE WORKS}

A common phenomenon on the World Wide Web is the creation of online frames for web-based content, provision of links from one site's to another site's content, and serving ads that appear to pop-up when users look at a website. ${ }^{196}$ Those who frame, link, or use pop-up ads generally do not ask permission from the sites affected. As with add-on software, frames, links, and pop-ups are based upon preexisting works in the loose sense of the word, and there is a way in which they might seem to recast the underlying content to which they are

191. Galoob, 964 F.2d at 969 .

192. Id. at 967.

193. Nintendo emphasized that the Game Genie had created a $\$ 150$ million market. The Ninth Circuit responded that "the existence of a market does not, and cannot, determine conclusively whether a work is an infringing derivative work. For example, although there is a market for kaleidoscopes, it does not necessarily follow that kaleidoscopes create unlawful derivative works when pointed at protected artwork." Id. at 969. Although the court concluded that the Game Genie did not infringe the derivative work right, it also ruled that even assuming that the Game Genie caused a derivative work to be created when users played games with the Game Genie, this would be a fair use of the Nintendo games. Id. at $969-71$.

194. Id. at 967 ("The examples of derivative works provided by the Act all physically incorporate the underlying work or works. The Act's legislative history similarly indicates that 'the infringing work must incorporate a portion of the copyrighted work in some form."' (quoting 1976 U.S.C.C.A.N. 5659, 5675)).

195. See id. at 969 (treating add-on software as derivative works "would chill innovation and fail to protect 'society's competing interest in the free flow of ideas, information, and commerce" (quoting Sony Corp. of Am. v. Universal Studios, Inc., 464 U.S. 417, 429 (1984))); see also Black \& Page, supra note 187 , at 634-35.

196. Loren, supra note 189 , at 59. 
connected in the online world. However, courts and commentators have been skeptical of derivative work claims involving these kinds of online connections. ${ }^{197}$

Only one U.S. case has considered a derivative work claim involving a defendant's framing of another website's content. In Futuredontics, Inc. $v$. Applied Anagramics, Inc., a website owner was denied a preliminary injunction that would have required the defendant to stop framing content posted on the plaintiff's site because the plaintiff had not shown a likelihood of success on the merits. ${ }^{198}$

Courts have similarly rejected claims that unauthorized pop-up ads created infringing derivative works. In Wells Fargo \& Co. v. WhenU.Com, Inc., the court considered whether WhenU's pop-up ads infringed Wells Fargo's derivative work rights in the contents of its website. ${ }^{199}$ As in Galoob, WhenU "only temporarily changes the way the sites are viewed by consumers. As soon as the advertisements are 'disconnected'-that is closed or minimized-plaintiffs' sites revert to their original form." 200 One copyright treatise author agrees that pop-up ads should not be considered infringements of derivative work rights because they "do not incorporate portions of the web pages they appear on, nor do they modify or alter the web pages."201 Although pop-ups may in some loose sense be based upon the content next to which they appear, they do not fall within the nine examples in the statutory definition, they are not analogous to the examples, ${ }^{202}$ and they do not recast the expression from the underlying content as required for the derivative work right to be infringed. Pop-ups may be beneficial in fostering new expression and wider public access to information on the web.

Another common phenomenon in the online world is the creation of word clouds or tag clouds, which visually depict the frequency of words or keywords in specific texts. To computing professionals, texts are not just (or even mainly) of interest because of the expression they contain but because they constitute

197. See, e.g., id. at 92-93 (arguing that techniques of digitally referencing online works-for example, by framing and linking-should not be treated as infringements of the derivative work right); see also Maureen A. O'Rourke, Fencing Cyberspace: Drawing Borders in a Virtual World, 82 MinN. L. REv. 609, 649 (1998) (arguing that framing, linking, and pop-ups should not infringe the derivative work right).

198. 45 U.S.P.Q.2d (BNA) 2005 (C.D. Cal. 1998), aff'd, 152 F.3d 925 (9th Cir. 1998). However, the defendant's motion to dismiss the claim that this infringed the derivative work right was also denied. Copyright commentators have been critical of framing-as-derivative work claims. See, e.g., PATRY, supra note $26, \S 12.18$ (opining that online framing does not create a derivative work, even if the original image may be partially obscured).

199. 293 F. Supp. 2d 734 (E.D. Mich. 2003).

200. Id. at 770; see also 1-800-Contacts, Inc. v. WhenU.Com, 309 F. Supp. 2d 467, 487 (S.D.N.Y. 2003) (pop-up ads do not implicate the derivative work right), rev'd on other grounds, 414 F.3d 400 (2d Cir. 2005).

201. PATRY, supra note $26, \S 12.19$.

202. See supra Part II for a discussion of characteristics of exemplary derivatives and analogues Pop-ups are nonanalogous because they do not appropriate any expression from the underlying works. 
databases of words from which, through computational analyses, it is possible to learn interesting things. Word clouds have been created, for instance, to compare two State of the Union addresses to show important differences in themes emphasized by the President in each speech. ${ }^{203}$ Word clouds are necessarily based upon preexisting works, and they recast the texts they represent, but only in a loose sense of the word. They are not derivative works because they do not appropriate expression from protected works; they do not recast the work but only words contained in the text. ${ }^{204}$ They are new expressions which enable learning.

\section{G. SUMMING UP: WHAT ARE AND ARE NOT DERIVATIVE WORKS}

Thus far, this Article has textually explained its conception of what is and is not within the derivative work right. It now offers a graphic representation in Table 2 of those creations that implicate the derivative work right and those creations that fall outside of the right, either because they are privileged or because they do not recast the underlying work's expression, as the nine exemplary derivatives do.

There are at least five reasons why derivative uses discussed in Part IV have been excluded from the scope of the derivative work right. First, authors do not have reasonable expectations of an entitlement to control these kinds of uses because Congress and the courts have decided that the right should not reach that far. Second, creative second comers are frequently willing to invest a considerable amount of time and energy in producing their own original derivative uses that may exploit a market niche that does not harm the markets in which the authors of the underlying works are operating or have reasonable expectations of operating in the future. Third, many derivative uses, such as indexes and commentaries, advance knowledge in keeping with the constitutional purpose of copyright law. Often, authors of the underlying works would not undertake these types of derivative use projects, but even if they did, it is socially desirable for second comers to be able to develop alternatives, some of which may be better than the authorized index or commentary. There is social benefit in allowing this kind of competition and follow-on innovation to occur. Fourth, there is no unjust enrichment if a second comer creates a market niche for these types of derivative uses that does not harm an author's primary or foreseeable derivative markets. Fifth, the autonomy and personal-property interests of owners of copies of protected works to modify them to make them more

203. See State of the Union Address, 2002 vs. 2011, WIKIPEDIA (Mar. 5, 2011), http://en.wikipedia.org/ wiki/File:State_of_the_union_word_clouds.png.

204. Professor Sag characterizes computational text mining and representations such as word clouds as nonexpressive uses of copyrighted works that should not give rise to copyright liability. See, e.g., Matthew Sag, Orphan Works as Grist for the Data Mill, 27 BERKELEY TECH. L.J. 1503, 1544 (2012). Sag prepared word clouds of common and uncommon words from Moby Dick and his article to show that these clouds do not make expressive uses of the texts they represent. See id. at 1519 figs.3 \& 4, 1550 fig.6. 
Table 2: Matrix of What Are and Are Not Potentially Infringing Derivative Works

\begin{tabular}{|c|c|c|}
\hline $\begin{array}{c}\text { Potentially Infringing } \\
\text { Derivatives }\end{array}$ & $\begin{array}{l}\text { Privileged } \\
\text { Derivatives }\end{array}$ & Not Derivative Works \\
\hline $\begin{array}{l}9 \text { examples } \\
\text { Close analogues: } \\
\text { - sequels } \\
\text { - prequels } \\
\text { - novelizations } \\
\text { Later emerging foreseeable } \\
\text { markets: } \\
\text { - videogames using movie } \\
\text { characters } \\
\text { New technology works } \\
\text { incorporating some } \\
\text { expression from the first } \\
\text { work: } \\
\text { - multimedia } \\
\text { encyclopedia } \\
\text { - database of data from a } \\
\text { print book }\end{array}$ & 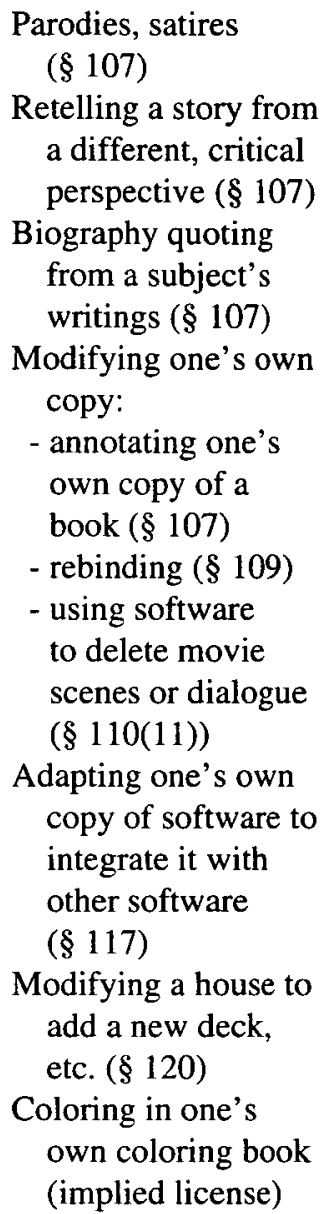 & $\begin{array}{l}\text { Useful articles depicted in } \\
\text { protected works ( } \$ 113) \\
\text { Supplementary works: } \\
\text { - test answer sheets } \\
\text { - commentaries } \\
\text { - bibliographies } \\
\text { - indexes } \\
\text { Reference works } \\
\text { Interoperable and add-on } \\
\text { software } \\
\text { Framing, linking, and pop-ups } \\
\text { Word clouds }\end{array}$ \\
\hline
\end{tabular}

useful for their purposes should be respected. We turn now to consider a set of derivative work cases that have given an unduly broad interpretation of the derivative work right.

\section{Problematic Derivative Work Cases}

This Part will consider several problematic decisions involving novel types of derivative works (that is, claims for derivative uses beyond the nine exemplary types or close analogues). In many of them, the definitional clause, "or any other form in which a work may be recast, transformed or adapted," was given a broad construction. Section A considers cases involving complementary works. 
Section B discusses cases in which purchased copies of protected works were repurposed, modified, or enhanced. Section $C$ examines challenges to artistic reworkings of other authors' works. Section D discusses a problematic decision involving a new product in a remote and unforeseen market. The analyses in these cases upholding infringement claims are weak and unpersuasive, and they cut off opportunities for competition and ongoing innovation as well as interfere with free-expression interests of subsequent creators.

\section{A. SHOULD COMPLEMENTARY WORKS INFRINGE THE DERIVATIVE WORK RIGHT?}

Complementary works are based upon preexisting works in the loose sense of this term, but they tend to be independently created works that make the goods they complement more valuable. ${ }^{205}$ Video games, for instance, are complementary goods to the platforms on which they operate. ${ }^{206}$

Complementary goods were held to infringe the derivative work right in a pair of cases against defendants who sold audio cassettes for insertion into the body of Teddy Ruxpin toy bears. ${ }^{207}$ When children pulled a cord in the bear's back, the cassettes played stories and caused the bear to move in a lifelike fashion. ${ }^{208}$ The defendants' cassettes were independently created works that told different stories, and competed with the plaintiff's tapes. In ruling that the defendant infringed, the court emphasized that the defendants admitted that they intended to capitalize on the success of this dancing bear toy, that the voices on the defendants' tapes were substantially similar to the voices on authorized tapes, and that playing the defendants' tapes caused the bear to move in ways

205. See, e.g., Bohannan \& HovenCAMP, supra note 99, at 53-54 (criticizing treating complements as infringing derivatives); Black \& Page, supra note 187, at 631 (arguing that complementary products such as add-on software "will increase the market value of the primary product by broadening the possible application or utility of that primary product"); Wu, supra note 24 . Because complementary works such as reviews often increase demand for the original work and do not take extensively enough to serve as a market substitute, Judge Posner believes that "copying that is complementary to the copyrighted work (in the sense that nails are complements of hammers) is fair use." Ty, Inc. v. Publ'ns Int'l Ltd., 292 F.3d 512, 517 (7th Cir. 2002).

206. It is easier to give examples of complementary goods than to define the term with precision. Examples include application programs as complementary goods to operating system programs, ink cartridges to printers, and test answer sheets to test documents. In the copyright context, complements may bask in some of the goodwill associated with the works to which they are complements. But insofar as they do not appropriate a substantial quantum of expression from the underlying work, complements should lie outside of the derivative work right. However, sometimes complements stray over the line when they draw too heavily upon detailed structural elements of the original. See, e.g., Twin Peaks Prods., Inc. v. Publ'ns Int'l, Ltd., 996 F.2d 1366, 1372-73, 1377 (2d Cir. 1993) (holding that a book consisting of plot summaries of Twin Peaks television programs was an unlawful abridgement); see also Addison-Wesley Publ'g Co. v. Brown, 223 F. Supp. 219, 227-28 (E.D.N.Y. 1963) (holding that manual of solutions to problems set forth in physics textbooks infringed because of some exact copying and close paraphrasing).

207. See, e.g., Worlds of Wonder, Inc. v. Veritel Learning Sys., Inc., 658 F. Supp. 351, 356 (N.D. Tex. 1986); Worlds of Wonder, Inc. v. Vector Intercontinental, Inc., 653 F. Supp. 135, 140 (N.D. Ohio 1986).

208. Vector, 653 F. Supp. at 137. 
substantially similar to those produced by the plaintiff's tapes. ${ }^{209}$ Because the defendants did not appropriate any expression from the plaintiff's works, these decisions have been subjected to withering criticism in the legal literature ${ }^{210}$ and have not been followed in subsequent decisions. The public has a legitimate interest in access to independently created tapes to tell stories, and these second comers had a free-expression interest in producing them.

A second complementary product found to be an infringing derivative was the speed-up chip in Midway Manufacturing Co. v. Artic International, Inc. ${ }^{211}$ Midway manufactured video-game machines with circuit boards loaded with game software in which Midway owned copyrights. Artic sold circuit boards loaded with independently developed software to Midway's customers. When Artic's circuit boards were installed in Midway machines, they caused Midway's Galaxian game to play faster. The court recognized that it was a stretch to apply the derivative work right to the speedup chip $^{212}$ but observed that "[s]peeding up a video game's action makes the game more challenging and exciting and increases the licensee's revenue per game."213 Because video-game owners "would undoubtedly like to lay their hands on some of that extra revenue," the court ruled that Artic had infringed the derivative work right. ${ }^{214}$ This decision is difficult to square with the legislative directive that the second work must have appropriated expression from the work on which it was based to infringe the derivative work right. ${ }^{215}$ It unreasonably hindered competition in the video-game industry.

Ty, Inc. v. Publications International, Ltd. is the leading case holding that complementary works do not infringe the derivative work right. ${ }^{216}$ Ty owned copyrights in Beanie Baby soft toys. Publications International Limited (PIL)

209. Id. at 139 .

210. See, e.g., PAtrY, supra note $26, \S 12.20$ (characterizing the Teddy Ruxpin cases as "[t]he most egregious" of the derivative work cases involving three-dimensional works); Dennis S. Karjala, Harry Potter, Tanya Grotter, and the Copyright Derivative Work Right, 38 ARIz. ST. L.J. 17, 29-30 (2006); Christian H. Nadan, Note, A Proposal to Recognize Component Works: How a Teddy Bears on the Competing Ends of Copyright Law, 78 CALIF. L. REv. 1633, 1651-54 (1990).

211. See 704 F.2d 1009, 1013 (7th Cir. 1983). Midway has been criticized by subsequent commentators. See, e.g., Black \& Page, supra note 187, at 633-34. This lawsuit also involved a set of circuit boards containing software that produced virtually identical audiovisual displays to Midway's Pac-Man game. Midway, 704 F.2d at $1010-11$. This aspect of the Midway ruling is unobjectionable.

212. Midway, 704 F.2d at 1014.

213. Id. at 1013.

214. Id. at 1013-14. But the court did not think a sped-up sound recording would infringe this right. Id.

215. See supra note 103 and accompanying text. A sped-up game might seem similar to the shorter version types of exemplary derivatives. However, abridgements and condensations actually appropriate expression from the works on which they are based; Artic's software, by contrast, did not contain any expression from Midway's games.

216. 292 F.3d 512 (7th Cir. 2002). For commentary supporting this proposition, see, for example, Wu, supra note 24, at 632-33, and see also Twin Peaks Prods., Inc. v. Publ'ns Int'l, Ltd., 996 F.2d $1366,1372-73,1377$ (2d Cir. 1993) (stating that " $[t]$ he author of 'Twin Peaks' cannot preserve for itself the entire field of publishable works that wish to cash in on the 'Twin Peaks' phenomenon" but holding that PIL's book was an unlawful abridgement). 
published a collector's guidebook about these toys that included photographs of them ${ }^{217}$ and provided "the release date, the retired date, the estimated value of the Beanie Baby, and other information relevant to a collector."218 In assessing Ty's derivative work claim, Judge Posner noted that "[t]he textual portions of a collectors' guide ... are not among the examples of derivative works listed in the statute, and guides don't recast, transform, or adapt the things to which they are guides." 119 PIL's guides were complementary goods to Ty's toys that posed no risk of supplanting demand for Ty's copyrighted Beanie Babies. ${ }^{220}$ The court recognized that it was necessary for PIL's guide to include photographs of the Beanie Babies, not just verbal descriptions, if it hoped to compete with similar guides licensed by Ty. ${ }^{221}$ An additional factor was that PIL's guidebooks were critical of Ty. ${ }^{222}$ The court recognized that if Ty could exclude PIL from the market of collector guidebooks, consumers would be deprived of this different voice about Ty's practices.

Ty is a more persuasive analysis of the complementary work issue than the Teddy Ruxpin and Midway decisions. It protected the free-expression interests of follow-on creators who were bringing new products to market and provided consumers with new choices. By focusing on whether the challenged work fell within the scope of the exemplary derivatives or recast or transformed the underlying work in a manner similar to the exemplary derivatives, Judge Posner made clear that the derivative work right does not confer on copyright owners an unbounded monopoly.

\section{B. DOES TINKERING WITH PURCHASED COPIES INFRINGE THE DERIVATIVE WORK RIGHT?}

Owners of copies of copyrighted works have, as explained earlier, some freedom to tinker with those copies under copyright exhaustion-of-rights principles. ${ }^{223}$ The main decision casting doubt on the viability of an exhaustion of

217. PIL apparently conceded that the photographs were derivative works of the Beanie Babies. Ty, 292 F.3d at 515. The Patry treatise contends that photographs are not derivative works of copyrighted works they depict. PATRY, supra note $26, \S 3.49$. However, if art reproductions of original paintings are derivative works, as the definition indicates, then photographs seem also to be derivative works. They are, after all, generally faithful renditions in a different medium that typically operate in a different market segment; photographs are often two-dimensional representations of three-dimensional works, as in Ty. Indeed, photographs of sculptural works such as Beanie Babies might actually be art reproductions under the 1976 Act. This is not to say that all photographs of copyrighted works (such as sculptures or architectural works) should be deemed infringing. There is, for instance, a special privilege for photographs of architectural works. See 17 U.S.C. $\$ 120$ (a) (2006). Fair use may protect many photographs of scenes in which copyrighted works are present. The Seventh Circuit panel reversed summary judgment in Ty because PIL's fair use defense had not been given adequate consideration. Ty, 292 F.3d at 524.

218. $T y, 292$ F.3d at 518-19.

219. Id. at 521 .

220. Id.

221. Id. Ty asserted that PIL could not lawfully publish color photos of the Beanie Babies and perhaps not even make black-and-white photos or sketches of them. Id.

222. Id at 519 (noting the analogy to critical reviews that fair use generally protects).

223. See supra section IV.B. 
rights defense to derivative work claims involving modifications to purchased copies is Mirage v. Albuquerque A.R.T. Co. ${ }^{224}$ Mirage owned copyrights in artistic images published in books. A.R.T. bought some of those books, cut the images out, and glued them onto ceramic tiles, which A.R.T. sold as wall hangings. The Ninth Circuit agreed with Mirage that A.R.T. infringed the derivative work right, saying that pasting the images onto tiles recast or transformed them and usurped a market opportunity that the artist's widow wanted to exploit. ${ }^{225}$ A.R.T. raised the first-sale/exhaustion-of-rights doctrine, but the court dismissed this defense out of hand because the statutory rule only limits the distribution right, not the derivative work right. ${ }^{226}$

Nearly identical facts were presented in Lee v. A.R.T. Co., but the Seventh Circuit declined to follow Mirage, pointing out that under that court's analysis, even framing or reframing artwork would infringe the derivative work right, a result that Congress could not possibly have intended. ${ }^{227}$ The court in Lee noted that tile art was not one of the exemplary types of derivatives in the statutory definition and the defendant had not adapted or recast the picture in any way, stating that "[i]t still depicts exactly what it depicted when it left Lee's studio." ${ }^{228}$ Because no derivative work had been created, Lee's copyrights were not infringed. ${ }^{229}$ A.R.T. had personal-property rights in the tiles and its copies of the art, and if consumers found its tile art attractive, this did not harm Lee.

Scholars agree that Lee is more persuasive than Mirage ${ }^{230}$ and the most recent case to have confronted the choice between Mirage and Lee followed the latter. ${ }^{231}$ Competition and ongoing innovation, as well as personal-property rights of owners of copies, will be fostered by limiting the derivative work right to instances in which second comers appropriate and transform protected expression from an underlying work. ${ }^{232}$

224. See Mirage Editions, Inc. v. Albuquerque A.R.T. Co., 856 F.2d 1341, 1344 (9th Cir. 1988); see also Greenwich Workshop v. Timber Creations, 932 F. Supp. 1210, 1214-15 (C.D. Cal. 1996) (following Mirage); Muñoz v. Albuquerque A.R.T. Co., 829 F. Supp. 309, 314 (D. Alaska 1993), aff'd, 38 F.3d 1218 (9th Cir. 1994) (following Mirage).

225. Mirage, 856 F.2d at $1343-44$.

226. Id. at 1344 .

227. See Lee v. A.R.T. Co., 125 F.3d 580, 582 (7th Cir. 1997). Lee is consistent with C. M. Paula Co. v. Logan, 355 F. Supp. 189, 192 (N.D. Tex. 1973) (holding that tile art did not infringe copyright).

228. Lee, $125 \mathrm{~F} .3 \mathrm{~d}$ at 582 .

229. The court pointed out that merely framing a copyrighted picture would not evince sufficient original expression to warrant a separate copyright in the framed picture as a derivative work, seemingly impressed by Lee's argument that the derivative work right could be infringed only when a second author had contributed enough original expression to the derivative to qualify for a copyright (assuming the derivative was lawfully made). Id. at 581-82.

230. See, e.g., Goldstein, supra note $22, \S 5.3$; Nimmer \& Nimmer, supra note $25, \S 3.03$; Patry, supra note $26, \$ 3.48$.

231. See Precious Moments, Inc. v. La Infantil, Inc., 971 F. Supp. 66, 69 (D.P.R. 1997) (holding that it was not an infringement of the derivative work right to make bedsheets out of copyrighted fabric).

232. PATRY, supra note $26, \S 3.48$ (noting that the authorship in an underlying work must be recast, transformed, or adapted to infringe the derivative work right). A better formulation is that the expression in the underlying work must have been transformed. An interesting decision reaching much 
Another questionable Ninth Circuit derivative work decision that involved tinkering with copies was Micro Star v. FormGen, Inc. ${ }^{233}$ The Duke Nukem video game created by FormGen came with a Build Editor through which users could create new levels for the game. FormGen encouraged users to share their digital files of new levels. Micro Star downloaded 300 new levels from the Web and burned the files onto CDs. ${ }^{234}$ FormGen claimed that the sale of these CDs infringed its copyrights. Relying on Galoob, Micro Star sought a declaratory judgment that its compilation was noninfringing. FormGen counterclaimed and sought a preliminary injunction against Micro Star's sale of the $C D$. The Ninth Circuit reversed a lower court ruling in Micro Star's favor, analogizing the user-created levels to sequels to stories FormGen created, which the court thought FormGen ought to be able to control. ${ }^{235}$ Because Micro Star's product, like the Game Genie in Galoob, did not incorporate expression from or permanently change the play of the Duke Nukem game but only called upon the functionality of FormGen's software, the Micro Star derivative work ruling is unpersuasive. ${ }^{236}$ Merely calling something a sequel does not automatically make it so; when sequels infringe, it is because their maker appropriated and transformed expression from the underlying work without authorization. Micro Star did not do this.

Tinkering with one's own copy of copyrighted works and selling those copies to the public is not, however, always immune from derivative work challenges. Clean Flicks learned this when it sought to satisfy an unmet demand for "clean" versions of popular DVD movies by ripping the movies it purchased off the disks, loading them onto computer hard drives, editing out sexually explicit and violent scenes as well as indecent language, and loading the edited movies onto

the same result was Theberge v. Galerie d'Art du Petit Champlain, Inc., [2002] 2 S.C.R. 336 (Can.), in which the Canadian Supreme Court permitted the purchaser of a copyrighted poster to transfer the image onto canvas for resale at a premium over the poster. Although the defendant changed the medium in which the work was available, the work itself was not transformed or adapted, and the poster was destroyed in the process of transferring the images from the poster to the canvas. Id.

233. 154 F.3d 1107, 1109-10 (9th Cir. 1998).

234. $I d$.

235. Id. at 1111-12. The reasoning in the Micro Star decision is unpersuasive. The authors of the add-ons at issue in the case were their user-creators. Micro Star may have infringed the users' copyrights by selling this compilation of add-ons, but the users did not sue for infringement. The add-ons merely called upon FormGen's functionality, as in Galoob. See notes 187-95 and accompanying text on the Galoob case.

236. For other criticism of the Micro Star decision, see, for example, Karjala, supra note 210 , at 28-29; Loren, supra note 189, at 73-74. One judge has said in dicta that designing a video recording device to enable consumers to skip commercials would "amount[] to creating an unauthorized derivative work." In re Aimster Copyright Litig., 334 F.3d 643, 647 (7th Cir. 2003). Some commentators have been skeptical of this claim. See, e.g., Abramowicz, supra note 78, at 383. A recently filed lawsuit challenging a commercial-skipping feature of a DVR alleges infringement of the reproduction and distribution rights but not of the derivative work right. See Complaint at 3, CBS Broad. Inc. v. DISH Network Corp., No. 2:12-cv-04551-PA-JCG (C.D. Cal. May 24, 2012). 
new DVDs for sale as family-friendly versions. ${ }^{237}$ The court found Clean Flicks to be an infringer based on the copies made in the editing process ${ }^{238}$ rather than on the edits themselves. Having decided that Clean Flicks made nontransformative uses of the movies when analyzing the fair use defense, the court seemed to believe that it could not conclude that the derivative work right had been infringed. ${ }^{239}$ This was erroneous because Clean Flicks's edits were enough like abridgements to fall within the derivative work right. Although infringement of the derivative work may be warranted in such a case, software designed to allow users to bypass violence, sexually explicit material, and foul language in DVD movies is analogous to the user-directed temporary changes of play in Galoob and thus should fall outside the derivative work right. ${ }^{240}$

Although exhaustion of rights may not provide owners with complete freedom to modify their copies, ${ }^{241}$ there is a growing sense that it would be wise to interpret exhaustion of rights flexibly in the digital age because user-innovators have become such important sources of new innovation. ${ }^{242}$ Construing the exhaustion-of-rights principle liberally in the digital age "would both increase the freedom of purchasers of products to modify the objects they now own and ... better align the law with public attitudes, in which the notion that you should be able to do what you want with something you have paid for is nearly universal." ${ }^{243}$ This is especially appropriate insofar as the modification is done to improve that copy in some way, to make it more useful for the purchaser's

237. See Clean Flicks of Colo., LLC v. Soderbergh, 433 F. Supp. 2d 1236, 1238 (D. Colo. 2006). The studios charged Clean Flicks with making unauthorized copies of the movies as well as distributing infringing copies of the edited films. Id. at 1239.

238. Id. at 1241-43. An interesting dimension of the Clean Flicks case was that the court assumed that "consumers of the edited versions would not have themselves purchased the authorized versions because of the objectionable content and the [s]tudios do not compete in this alternative market." Id. at 1242. The court deferred to the studios' judgments about which versions of their movies should be available in the marketplace. Id. Less persuasive as a derivative work case is National Bank of Commerce v. Shaklee Corp., 503 F. Supp. 533, 543 (W.D. Tex. 1980) (holding that the insertion of ads in purchased copies of books infringed copyright). Shaklee relied upon Gilliam v. American Broadcasting Co., 538 F.2d 14 ( $2 \mathrm{~d}$ Cir. 1976), but that decision is distinguishable because ABC actually transformed expression from Gilliam's work, id. at 18, 21; Shaklee did not, id. at 543-44. Insofar as Shaklee gave consumers a false impression about Heloise's endorsements of its ads, liability predicated on that ground is sound. But the copyright ruling is questionable.

239. Clean Flicks, 433 F. Supp. $2 \mathrm{~d}$ at $1241-42$.

240. See supra notes 188-94 and 141-43 and accompanying texts for discussion of Galoob and ClearPlay.

241. After all, the statutory right of owners of copies to modify software and alter architectural .works would be unnecessary if ownership of the software or the building automatically meant the owner was free to make modifications. See supra section IV.B.

242. See, e.g., Eric von Hippel, Democratzing Innovation 19-21 (2005) (giving examples); William W. Fisher III, The Implications for the Law of User Innovation, 94 MINN. L. REv. 1417, 1418-22 (2010) (giving examples); see also Pamela Samuelson, Freedom to Tinker, in Revolutionizing InNovation: Users, COMmunities and Open InNovation (Dietmar Harhoff \& Karim Lakhani eds., forthcoming 2013).

243. Fisher, supra note 242, at 1475. 
purposes, or to actualize the purchaser through creative play. ${ }^{244}$

\section{WHEN SHOULD ARTISTIC TRANSFORMATIONS BE FAIR USES?}

Some creators who modify their copies of copyrighted works for resale to the public do so for artistic reasons. Susanne Pitt, for instance, was an artist who bought Barbie dolls, which she repainted and recostumed for resale online as sadomasochistic "Dungeon Dolls" for adult customers, and offered customizing services for Barbies to her clients. ${ }^{245}$ Mattel sued for infringement of its derivative work right in Barbie dolls and moved for summary judgment. Because Pitt had a plausible fair use defense, the trial judge denied Mattel's motion. ${ }^{246}$ The court noted that Pitt made transformative uses of the dolls and also that Mattel neither offered for sale nor licensed the manufacture of sadomasochistic Barbies, so Pitt's dolls were unlikely to supplant demand for this kind of derivative. ${ }^{247}$ Perhaps the judge also should have considered Pitt's interests in freedom of artistic expression as weighing in favor of fair use. ${ }^{248}$ Furthermore, he should have questioned whether the resale of purchased Barbie dolls dressed by Pitt in her independently created costumes could potentially infringe the derivative work right. ${ }^{249}$

Artistic reworkings of existing images have a longstanding history in the visual arts. Pablo Picasso, Georges Braque, Marcel Duchamp, Andy Warhol, and Robert Rauschenberg are among the giants of the twentieth-century art world who incorporated or transformed existing images in their collages and paintings. Only fairly recently have copyright owners in the underlying images brought suit to challenge these kinds of reworkings as copyright infringement. ${ }^{250}$

The best known of these recent lawsuits was Fairey v. Associated Press,

244. See supra note 5 (citing early case law privileging improvements); see, e.g., Fisher, supra note 242, at 1455-74 (discussing self-actualization); Mark A. Lemley, The Economics of Improvement in Intellectual Property Law, 75 Tex. L. Rev. 989 (1997) (arguing that copyright should be more open to improvements).

245. See Mattel, Inc. v. Pitt, 229 F. Supp. 2d 315, 318-19 (S.D.N.Y. 2001); see also Mattel Inc. v. Walking Mountain Prods., 353 F.3d 792, 812 (9th Cir. 2003) (holding that photographs of nude Barbie dolls imperiled by household appliances were fair use).

246. Pitt, 229 F. Supp. 2 d at 325.

247. Id. at $321-25$.

248. See id. at 319.

249. After all, Pitt bought the dolls in the market and made the costumes herself. Copyright in a doll is not infringed by making clothes for it because the clothing does not transform the doll's expression. There are many unlicensed makers of Barbie doll clothing. It is perhaps a closer question whether repainting Barbie dolls would pose derivative work problems, but this case involved only the application of makeup to the doll, which seems a de minimis use. The Dungeon Dolls website can be found at web.archive.org/web/20000821123025/http://dungeondolls.com. The court did not discuss the derivative work right but assumed that repainting or recostuming the dolls could "be characterized as copying or as otherwise violative of the copyright holder's protected rights in the work." Id. at 321.

250. Two other derivative work cases involving creative reuses of existing images are Rogers $v$. Koons, 960 F.2d 301, 312 (2d Cir. 1992) (holding that an artist's three-dimensional sculpture based on a photograph of a couple holding a set of puppies was not fair use), and Blanch v. Koons, 467 F.3d 244, 259 (2d Cir. 2006) (holding that it was fair use for a graphic artist to use part of a photograph in a painting). 
which involved Shepard Fairey's creative reworking of a photograph, taken by Mannie Garcia for the Associated Press of then-presidential-candidate Barack Obama, that resulted in the now-famous and colorful "Obama Hope" poster. Fairey sought a declaratory judgment that the poster made fair use of the photograph, which was highly transformative of the photograph; his fair use claim was, however, tainted by his misrepresentations and destruction of some evidence relating to the photograph. ${ }^{251}$ The Fairey case ultimately settled with both litigants asserting they had not surrendered their position. ${ }^{252}$ Fairey's Obama Hope poster, in turn, gave rise to a substantial number of creative reworkings, none of which has been challenged as an infringing derivative work. ${ }^{253}$

Gaylord v. United States was another recent case challenging an artistic reworking of an existing image as an infringing derivative work. ${ }^{254}$ Frank Gaylord was selected to create a sculpture of soldiers in formation, known as The Column, as part of the Korean War Veterans Memorial for the National Mall in Washington, D.C. ${ }^{255}$ Shortly after the memorial was dedicated, John Alli took a set of photographs of The Column as a retirement gift for his father, one of which featured a subset of the sculptured soldiers covered with snow. The U.S. Postal Service eventually decided to use a grayer version of this image on a stamp, 48 million of which were sold to the public. Gaylord sued the government for infringement, and the government claimed fair use. ${ }^{256}$

The trial court regarded the photograph as well as the stamp to be transformative in the Campbell sense of the term because it "creat[ed] a surrealistic environment with snow and subdued lighting where the viewer is left unsure whether he is viewing a photograph of statues or actual human beings."257 When recast into a monochromatic stamp, the Postal Service's version was even more transformative. The Federal Circuit, however, decided that the stamp was nontransformative because the stamp and The Column had the same purpose of honoring Korean War veterans. The court noted that "[n]ature's decision to snow cannot deprive Mr. Gaylord of an otherwise valid right to exclude." ${ }^{\text {258 }} \mathrm{A}$ second factor supporting the lower court's fair use ruling was that the stamp had caused no harm to the market for The Column or derivative works of it. On this point, the Federal Circuit agreed: "Someone seeking to take a photograph of

251. Complaint for Declaratory Judgment and Injunctive Relief and Demand for Jury Trial at 12-13, Fairey v. Associated Press, No. 1:09-cv-01123-AKH (S.D.N.Y. Feb. 9, 2009). For a discussion of the lawsuit and controversy over the Obama Hope poster, see, for example, William W. Fisher III et al., Reflections on the Hope Poster Case, 25 HaRv. J.L. \& TeCH. 243 (2012).

252. See, e.g., Randy Kennedy, Shepard Fairey and the A.P. Settle Legal Dispute, N.Y. Times (Jan. 12, 2011), http://www.nytimes.com/2011/01/13/arts/design/13fairey.html.

253. See, e.g., Fisher, supra note 251, at 334-38 (showing examples of creative reworkings of the poster).

254: 595 F.3d 1364 (Fed. Cir. 2010).

255. Id. at $1368-75$.

256. Id.

257. Id. at 1372-73 (quoting Gaylord v. United States, 85 Fed. Cl. 59, 68-69 (2008)).

258. Id. at 1374 . 
The Column or otherwise create a derivative work would not find the stamp to be a suitable substitute for The Column itself." 259 Yet, having decided that three other factors-the commercial purpose of the Postal Service, the creativity in Gaylord's sculpture, and the substantiality of the taking - weighed against fair use, a majority of the court ruled that the government infringed the derivative work right. ${ }^{260}$

One judge in Gaylord dissented, pointing out that The Column was a work of public art and indeed part of a national monument that had been commissioned by the government under a contract that gave it "unlimited rights" to make use of government-commissioned works. ${ }^{261}$ She would have deferred to the lower court's holding of transformativeness and would not have overturned it as clearly erroneous. She also rightly worried about the chilling effect this ruling could have on the public's ability to use the memorial as intended. ${ }^{262}$

The most troubling case holding that artistic reworkings of existing images infringe the derivative work right was the district court ruling in Cariou v. Prince, ${ }^{263}$ which was recently reversed in large part and also vacated by the Second Circuit Court of Appeals. Patrick Cariou is a professional photographer who took a series of photographs of Rastafarians in Jamaica, reproductions that he published in a book in 2000. In 2007, Richard Prince, a well-known artist whose works have been shown in the Guggenheim Museum and sold in top New York galleries, purchased copies of Cariou's book, tore out numerous images from the books, and used them in a series of twenty-nine works of art to which Prince gave the name Canal Zone. ${ }^{264}$ Prince used some images from Cariou's book to make collages; with others, he painted over portions of the photographs, sometimes using the whole and sometimes using only parts of the photos. ${ }^{265}$

When Cariou sued him for copyright infringement, Prince asserted fair use. In the district court, Judge Batts granted Cariou's motion for summary judgment, ruling against Prince on every fair use factor. ${ }^{266}$ She ruled that there was

259. Id. at 1375 .

260. Id. at $1374-76$.

261. Id. at $1381-85$.

262. Id. at 1385-86. Those who commissioned the sculpture must have expected that visitors would take photographs of it, which the Federal Circuit's ruling would seem to make a prima facie infringement.

263. 784 F. Supp. 2d 337 (S.D.N.Y. 2011), rev'd in part, vacated in part, 2013 WL 1760521 (2d Cir. Apr. 25, 2013).

264. Images of Prince's and Cariou's works are included in an Appendix to the Second Circuit opinion, Cariou v. Prince, 2013 WL 1760521, available at http:/www.ca2.uscourts.gov/11-1197apx.htm. Several of Prince's works and Cariou's photographs were also reproduced in the Brief of Amicus Curiae The Andy Warhol Foundation for the Visual Arts, Inc. in Support of Defendants-Appellants and Urging Reversal at 3, 28-31, Cariou v. Prince, No. 11-1197-CV (2d Cir. 2011) [hereinafter Warhol Amicus Brief].

265. Cariou, 784 F. Supp. $2 d$ at 343-44.

266. Id. at 354. Cariou also sued the Gagosian Gallery for direct infringement for the public display of Prince's Canal Zone works, for reproducing and distributing copies of these infringing derivatives in 
"vanishingly little, if any," transformativeness in Prince's paintings because he did not claim to be using Cariou's photographs to comment on them. ${ }^{267}$ "[T]o the extent they merely recast, transform, or adapt the Photos, Prince's Paintings are instead infringing derivative works." ${ }^{268}$ Also weighing against fair use, in her view, was the commerciality of Prince's purpose in reusing Cariou's images, which was evident from the more than $\$ 10$ million received from sales of eight of the Canal Zone paintings. ${ }^{269}$ Even more damning to the judge was Prince's failure to seek a license from Cariou, which showed his bad faith. ${ }^{270}$ The "highly original and creative" nature of Cariou's photographs and the amount and substantiality of the taking from Cariou's work cut further against fair use. ${ }^{271}$ Judge Batts also concluded that "Prince has unfairly damaged both the actual and potential markets for Cariou's original work and the potential market for derivative use licenses for Cariou's original work." 72 So outraged was this judge by Prince's paintings that she ordered him to deliver up the remaining Canal Zone paintings under his control to Cariou for impoundment and destruction. ${ }^{273}$

On appeal, the Second Circuit held Prince's use to be fair as to twenty-five of the thirty works in question. ${ }^{274}$ The court rejected Judge Batt's conclusion that Prince's paintings were transformative only if they commented on Cariou's works as an erroneous interpretation of the Supreme Court's ruling in Campbell. ${ }^{275}$ The central inquiry under that ruling is whether the challenged work supersedes the original work or instead "adds something new, with a further purpose or different character, altering the first with new expression, meaning, or message."276 Prince's paintings unquestionably added something new and changed the meaning and message of Cariou's images, regardless of Prince's intentions. ${ }^{277}$

an exhibition catalog, and for vicarious and contributory infringement liability. Judge Batts ruled against Gagosian on all counts as well as against Prince. Id. at 354-55.

267. Id. at 350 .

268. Id. at 349 .

269. Id. at $350-51$.

270. Id. at 351 .

271. Id. at 352 .

272. Id. at 353 .

273. Id. at 355-56. The Gagosian Gallery was similarly ordered to deliver paintings, exhibition catalogs, and other copies of Prince's Canal Zone work for impoundment and destruction. Id. The defendants were also ordered to notify current and future owners of the Canal Zone paintings that they were infringing derivative works that could not lawfully be publicly displayed. Id.

274. Cariou v. Prince, No. 11-1197-cv, 2013 WL 1760521, at*10 (2d Cir. Apr. 25, 2013). The court remanded the remaining five works to the district court to determine whether the alterations in those works constitute a fair use. $I d$.

275. Id. at *5-6.

276. Campbell v. Acuff-Rose Music, Inc., 510 U.S. 569, 579 (1994). The Second Circuit disavowed a comment or criticism test for transformativeness in Bill Graham Archives v. Dorling Kindersley Ltd, 448 F.3d 605, 606 (2d Cir. 2006).

277. Cariou v. Prince, 2013 WL 1760521, at *6 (comparing Cariou's "serene and deliberately composed portraits and landscape photographs" with Prince's "hectic and provocative" works). The 
Also erroneous under Campbell was the heavy emphasis Judge Batts placed on the commercial nature of Prince's work and on Prince's failure to seek a license from Cariou. ${ }^{278}$ Because Prince's paintings alter the expression in Cariou's images in ways that seemingly offended Cariou's sensibilities, it was unlikely that Cariou would be willing to license the making of such derivatives. ${ }^{279}$ Nor was it likely that Prince's paintings would have a negative effect on the market for Cariou's photographs because the paintings appeal to a different market segment than Cariou's photographs. ${ }^{280}$

Nor should it matter, under Campbell, if Prince's use of Cariou's images was (in the judge's view) in bad taste. ${ }^{281}$ In cases such as Pitt and Cariou, there is reason to be concerned that the rights holder is asserting a derivative work claim mainly because it wants to censor artistic expression of which it does not approve or to gain moral-rights protection unavailable to the underlying works. ${ }^{282}$ U.S. law does not generally protect the moral right of authors to control modifications to purchased copies of their works, even though such rights are widely recognized in the international arena. ${ }^{283}$ Only a narrow set of works of visual art qualify for protections under the Visual Artists Rights Act of 1990 (VARA) against "any intentional distortion, mutilation, or other modification of [a visual artist's] work which would be prejudicial to his or her honor or reputation." ${ }^{284}$ A logical implication of the narrowness of VARA rights is that modifications to works not protected by VARA should not generally violate the derivative work right. Otherwise, the derivative work right would indirectly give moral rights protections to authors whom Congress has chosen not to grant VARA protections, ${ }^{285}$ as appears to have happened in the lower court in Cariou.

Warhol amicus brief explains the differences in messages of the Cariou photographs and the Prince paintings. See Warhol Amicus Brief, supra note 264, at 28-31.

278. Cariou v. Prince, 2013 WL 1760521, at *7 (holding that commerciality does not weigh against fair use when the second comer's use is transformative (citing Campbell, 510 U.S. at 584, 579)). Nor is the failure to get license a sign of bad faith. See Campbell, 510 U.S. at 592-93.

279. Cariou's request for an order to deliver the remaining Canal Zone paintings to him for impoundment and destruction suggests that he finds their content objectionable.

280. Cariou v. Prince, 2013 WL 1760521 , at *8.

281. Campbell, 510 U.S. at 582-83. Judge Batts's disdain for Prince and his art is evident from her description of his testimony. See Cariou v. Prince, 784 F. Supp. 2d 337, 349-51 (S.D.N.Y. 2011).

282. See, e.g., Lee v. A.R.T. Co., 125 F.3d 580, 582-83 (7th Cir. 1997) (expressing concern about broad derivative work claims as an effort to get moral rights protection for works not qualifying for it under 17 U.S.C. $\S \S 101,106 \mathrm{~A}(\mathrm{a})$ ).

283. See Berne Convention, supra note 36 , at art. 6 bis.

284. 17 U.S.C. $\$ \S 101,106$ A(a)(3) (2006). Photographs qualify for VARA protection only if made, for exhibition purposes, existing either in a single copy or in a limited edition of 200 or fewer copies signed and consecutively numbered by the author. $I d$. $\$ 101$. Reproductions of photographs protected by VARA do not, however, qualify for visual-art protection. Id. $\$ 106 \mathrm{~A}(\mathrm{c})(3)$. Thus, even if Cariou's photographs had been protectable by VARA (which they were not), the reproductions used by Prince in his visual art would be ineligible for VARA protection.

285. At the very least, the user's ownership of a copy should tip in favor of fair use, even if courts decide that the exhaustion doctrine does not limit the derivative work right. 


\section{SHOULD THE DERIVATIVE WORK RIGHT EXTEND TO DERIVATIVE USES IN REMOTE AND UNFORESEEN MARKETS?}

The derivative work right most clearly extends to works operating in foreseeable markets such as those implicated by the nine exemplary derivatives in the statutory definition and close analogues. ${ }^{286}$ The rationales for granting derivative work rights, discussed in Part III, also anticipate foreseeable markets. For example, incentives to create new works of authorship may be grounded for some creators upon expectations of rights to recoup research-and-development costs through control over readily foreseeable markets, such as the nine exemplary derivatives in the definition. But if first-generation creators do not foresee opportunities in remote markets, it is unclear that their incentives to create will be diminished if others perceive and then act on the imagined new market. The justification that defers to the interests of creators in taking reasonable time (to decide which derivative markets to enter and under what conditions) also seems inapposite as applied to unforeseen and remote markets. The unjust enrichment justification is similarly plausible as to foreseeable markets but not to unforeseen and remote markets. ${ }^{287}$ The statutory argument for extending the derivative work right beyond foreseeable markets is thus weak.

There are important policy reasons to limit the derivative work right to foreseeable markets. Entrepreneurial second comers may perceive opportunities to create new products and markets that consumers will find attractive. Copyright owners cannot be harmed by unforeseeable uses and their incentives to invest in the underlying work and foreseen derivatives will not be affected by the new uses second comers imagine and implement. ${ }^{288}$ Limiting the reach of the derivative work right will encourage follow-on creators to make new works of authorship that will add to the store of knowledge, enrich culture, and entertain the public in ways that the copyright owner has not done and probably

286. See, e.g., Shyamkrishna Balganesh, Foreseeability and Copyright Incentives, $122 \mathrm{HARv}$. L. REv. $1569,1603-25$ (2009) (proposing that courts in copyright cases pay more attention to whether harm to the market was foreseeable before deciding that a defendant's use undermined incentives to create); Ghosh, supra note 71, at 351 (calling for more careful analysis of market harm in derivative work cases).

287. A market may, of course, be unforeseen by the author of an underlying work when a second comer first exploits a remote market but become foreseeable once the second comer has entered it. After the Casile Rock case, for instance, trivia games based on television programs would be more a foreseeable derivative market once Carol identified this market niche. See infra notes $290-300$ and accompanying text. Yet this does not mean that this niche has become a "traditional, reasonable, or likely to be developed" market that copyright owners are entitled to control. See, e.g., Bill Graham Archives v. Dorling Kindersley Lid., 448 F.3d 605, 614-15 (2d Cir. 2006). Copyright owners are not entitled to control markets when second comers make transformative uses of their works. Id. The mere fact that a copyright owner wants license revenues from a second comer does not, of itself, make the use one that the owner is entitled to control. Id.

288. Professor Newman has proposed that "a use should be regarded as unforeseeable to the author, and consequently outside the author's rights, when we can say with confidence that the benefits derived from a putative copy of the work do not stem from recreation of the expressive experience the author designed." Newman, supra note 24 , at 304. 
will never do. The public has a legitimate interest in the existence of new works in markets for unforeseen derivative uses of protected works. Even if there is some free riding on the plaintiffs' contributions in such cases, courts would do well to remember that free riding, as long as it is not predatory, is socially valuable. ${ }^{289}$

The main case to the contrary is Castle Rock Entertainment, Inc. v. Carol Publishing Group, Inc. ${ }^{290}$ Castle Rock owned copyrights in eighty-six episodes of the popular television show Seinfeld. Carol developed a trivia game that used snippets from eighty-four of those programs in posing questions and proffering answers that Seinfeld fans might find interesting or challenging. ${ }^{291}$ The Seinfeld Aptitude Test (SAT) was a 132-page book containing 643 trivia questions (multiple-choice, short answer, and matching questions). Although some SAT questions called upon users to identify which character had made certain quoted remarks, the overwhelming majority of the trivia questions and answers were neither quotations nor close paraphrases; they just contained some details or short quotes that called for familiarity with the programs and tested how much fans knew about the characters, events, and scenes from the series. Carol contributed expression to the quiz by making up the questions and the "incorrect answers" as well as selecting and arranging the material drawn from the programs. ${ }^{292}$

The Second Circuit in Castle Rock decided that the SAT trivia game was substantially similar to the Seinfeld programs and hence infringed copyright, even though none of the conventional tests for infringement of the reproduction right would have predicted this outcome. ${ }^{293}$ The court decided to treat the eighty-four programs at issue as one copyrighted work-a highly questionable proposition-and rejected Carol's argument that most of what it had appropriated from the programs were facts about the characters and events in the series to which copyright protection does not extend. ${ }^{294}$ Because these details were

289. See, e.g., Mark A. Lemley, Property, Intellectual Property, and Free Riding, 83 TEx. L. Rev. $1031,1046-50(2005)$

290. 150 F.3d 132 (2d Cir. 1998).

291. Id. at 135-36. It asked, for instance, whether one of the male characters on the show had tried to impress a woman by holding himself out as "a) a gynecologist[,] b) a geologist[,] c) a marine biologist[, or] d) a meteorologist." ld. at 135 .

292. Id. at $135-36$.

293. The court acknowledged that under the widely used ordinary-observer test, there would be no liability because the SAT did not have the same aesthetic appeal as the television programs. $1 d$. at 139-40. Nor was the total concept and feel of the SAT substantially similar to that of the Seinfeld programs, even though this test is also sometimes used in judging whether the reproduction right has been infringed. Id. at 140 . The court noted that this test was "not helpful in analyzing works that, because of their different genres and media, must necessarily have a different concept and feel." Id. Furthermore, neither the fragmented nonliteral similarity nor comprehensive nonliteral similarity tests would have predicted that Carol would be held to have infringed the reproduction right. Id. The court did not directly consider whether Carol infringed the derivative work right, although this was a somewhat more plausible theory of liability.

294. Id. at 138. The Nimmer and Patry treatises are critical of Castle Rock's treatment of the 84 programs at issue as one work as well as skeptical about its holding. NIMMER \& NiMMER, supra note 25, 
fictional, the court regarded the details as part of the work's protectable expression. ${ }^{295}$

Although Castle Rock had not developed its own Seinfeld trivia game, and hence the SAT was not usurping a market that Castle Rock had its eye on, the court noted that Castle Rock had been carefully managing licensing markets for products related to Seinfeld as a reason to defer to the owner's judgment about which markets to enter or not. ${ }^{296}$ The court's treatment of Carol's fair use defense was more dismissive than convincing. ${ }^{297}$

The Castle Rock decision would have been somewhat more plausible (although still unconvincing) had it analyzed the SAT as a derivative work. To say that the trivia game questions and answers were "copies" of the Seinfeld television programs, as the court concluded, is simply specious. ${ }^{298}$ Yet the SAT was unquestionably based upon the Seinfeld programs, and it can be said to have recast hundreds of specific details from the programs in a different form. If one considers the last clause of the derivative work definition to be an openended and entirely separate basis for derivative work liability, rather than, as this Article argues, a part of the definition that should be construed in relation to the other parts, it would be possible to conclude that the derivative work right was implicated in Carol's publication of the SAT.

However, the SAT had no impact on Castle Rock's ability to recoup its investments in the Seinfeld program, and as the court noted, the programs became even more popular and lucrative after the SAT was published than they had been before. ${ }^{299}$ Castle Rock did not show that the SAT interfered with any of its licensing markets. The SAT made clear that it was not a licensed derivative, so there was no chance that consumers would be confused about

$\S 13.03$ [A][3]; PATRY, supra note $26, \S 10: 66$. On the unprotectability of facts and the right of second comers to appropriate them, see Feist Publ'ns, Inc. v. Rural Tel. Serv. Co., 499 U.S. 340 (1991). Feist did not, however, consider whether information about what transpired in a work of fiction should be treated as a fact.

295. Castle Rock, $150 \mathrm{~F} .3 \mathrm{~d}$ at 139.

296. Id. at 145-46. Even if Castle Rock had created a trivia game based on the Seinfeld series, this should not necessarily mean that Carol's SAT was illegal. Castle Rock would presumably have had a competitive advantage over Carol in being the source of the programs. Carol's existence in the game market would have given consumers a choice between its product and Castle Rock's and would have spurred Castle Rock to make a better game than Carol's in order to compete on the merits.

297. See id. at 141-46. The court was particularly dismissive of the purpose of the defendant's use factor, characterizing the SAT as having only a "slight to non-existent" transformative nature. Id. at 142. This is inconsistent with a Supreme Court precedent which says that uses are transformative when the use is for a different purpose than the copyright owner's use. See, e.g., Campbell v. Acuff-Rose Music, Inc., 510 U.S. 569, 579 (1994).

298. Castle Rock, 150 F.3d at $137-41$.

299. Id. at 136. Professor Abramowicz has suggested that courts should only find derivative works to be infringing where the economic function of the right is being served. Abramowicz, supra note 78, at 325 . 
this. ${ }^{300}$ The SAT required substantial creativity to produce, transforming aspects of the works from which it drew in a different way than Castle Rock and its licensees had done, and it offered Seinfeld fans another resource with which to indulge their passions for this particular set of popular-culture icons. The SAT was neither one of the nine exemplary derivatives nor analogous in characteristics; the trivia game did not recast or transform the shows and none of the justifications for the derivative work grant justify the court's decision. Accordingly, the court should not have found infringement of the derivative work right. Cases such as Castle Rock have the unfortunate consequence of encouraging other far-fetched derivative work claims, ${ }^{301}$ which is yet another reason to conclude that the derivative work right should not extend to remote and unforeseen markets. ${ }^{302}$

\section{CONCLUSION}

The derivative work right of U.S. copyright law confers on authors the right to control translations of literary works, rearrangements of music, and other named or analogous derivatives, which operate either in the same or a foreseeable market segment. The open-ended final clause of the derivative work definition has created flexibility so that the derivative work right can properly be applied to some transformations not explicitly identified in the definition. It was, after all, a perceived virtue of the 1976 Act that its exclusive-rights provisions were more streamlined and general than the 1909 Act exclusiverights provisions had been, ${ }^{303}$ and there was reason to believe that the technological advances would make possible new types of transformations that Congress could not foresee and for which it could not explicitly provide.

There is, however, no credible evidence that Congress intended to create a vast and open-ended expansion of derivative work rights by inserting that last clause into the definition. Indeed, the point of including nine exemplary types of derivatives in the definition was to give some guidance about the kinds of derivatives Congress had in mind. The most reasonable way to interpret this clause when applying it to a novel type of derivative work claim is to examine the nine exemplary derivatives and consider whether the challenged work is

300. See Castle Rock, 150 F.3d at 136. In some cases, the plaintiff's indifference to derivativeuse markets has cut against its claims of infringement. See, e.g., Warren Publ'g Co. v. Spurlock, 645 F. Supp. 2d 402, 425 (E.D. Pa. 2009).

301. See, e.g., Ty, Inc. v. Publ'ns Int'l Ltd., 292 F.3d 512 (7th Cir. 2002) (discussed supra notes 216-22 and accompanying text); Warner Bros. Entm't Inc. v. RDR Books, 575 F. Supp. 2d 513 (S.D.N.Y. 2008) (discussed supra notes 174-79 and accompanying text).

302. See Abramowicz, supra note 78, at 373 (arguing that the derivative work right may be violated if defendant is exploiting a plausible market); Amy B. Cohen, When Does a Work Infringe the Derivative Works Right of a Copyright Owner?, 17 CARDOzo ARTs \& ENT. L.J. 623, 657 (1999) (arguing that there is derivative work right infringement if a defendant is invading a customary and anticipated market).

303. See, e.g., Robert A. Gorman, An Overview of the Copyright Act of 1976, 126 U. PA. L. Rev. $856,874-75(1978)$. 
analogous to one or more of the nine examples. Infringement should be found only where an analogous use has been made, as recent decisions such as $R D R$ and $T y$ have recognized.

This Article has shown that, for the most part, courts have kept the derivative work right within sound boundaries. Subsequent cases have not followed the deviant analyses of Worlds of Wonder or Midway, both of which failed to heed a key limiting principle of the derivative work right intended by Congress, namely, that the derivative work right cannot be infringed unless the second work incorporates a substantial quantum of expression from the underlying work. FormGen notwithstanding, the case law involving unauthorized development of interactive works has declined to adopt expansive interpretations of the last clause of the derivative work definition. Although the Ninth Circuit has yet to abjure its erroneous interpretation of the derivative work right in Mirage, subsequent cases outside that circuit have not followed its lead. Harsh criticism of Mirage by other courts, by treatise authors, and by other commentators seems to have stemmed the mischief that that case has wrought. Like Mirage, the Castle Rock decision has been subject to some withering criticism, and although it continues to have some influence in the case law, courts have generally been careful not to interpret it as expansively as some copyright owners have wanted. ${ }^{304}$

The most troublesome cluster of derivative work cases are those involving artistic reworkings of existing images. The fair use defenses in Fairey, Gaylord, and Cariou had more merit, in my view, than the judges presiding over them perceived. But those cases were close ones. Yet, even if courts decide the boundaries of fair use have been exceeded, they should forbear issuing orders to impound and destroy the resulting art works. ${ }^{305}$ In view of the public's interest in access to art, creative reworkings should give rise to compensatory awards, not injunctive relief. ${ }^{306}$

304. J.K. Rowling and Warner Brothers relied on Castle Rock in their challenge to RDR's publication of the Harry Potter Lexicon book, arguing that details about Harry Potter, his friends, his enemies, and the like were protectable expression that RDR had no right to publish. See RDR, 575 F. Supp. 2d at 536. Ty also relied on Castle Rock in its challenge to the PIL collector's guidebook. Ty, 292 F.3d at 522-23. Judge Batts also relied quite heavily on the Castle Rock decision, citing it repeatedly. See Cariou v. Prince, 784 F. Supp. 2d 337, 348-53 (S.D.N.Y. 2011). The judges in the $T y$ and $R D R$ cases rejected the expansive interpretations of Castle Rock. See Ty, 292 F.3d at $523 ; R D R, 575$ F. Supp. 2d at 539.

305. I agree with the sentiment expressed by Judge Parker during the oral argument to the Second Circuit in Cariou that an injunction requiring destruction of Prince's works was "something that would appeal to the Huns or the Taliban." Donn Zaretsky, Prince-Cariou Oral Argument, ARr L. BLog (May 21, 2012, 11:19 PM), http://theartlawblog.blogspot.com/2012/05/prince-cariou-oral-argument. html.

306. Campbell v. Acuff-Rose Music, Inc., 510 U.S. 569, 578 n.10 (1994); see Leval, supra note 89, at 1132 ("Yet there may be a strong public interest in the publication of the secondary work. And the copyright owner's interest may be adequately protected by an award of damages for whatever infringement is found."); see also Geller, supra note 123, at 61 (arguing against injunctions for creative reworkings); Rubenfeld, supra note 123, at 55 (same). If courts do withhold injunctive relief in creative-reworking cases, they also ought to make an equitable exception to the rule that infringing 
As courts come to recognize that there are many policy reasons for limiting the scope of the derivative work right, that the rationales for the derivative work right provide a basis for limiting its reach, that this right does not extend to all derivative uses, and that fair use and other privileges have an important role in limiting derivative rights, it will finally be possible to build a sound conceptual foundation for the derivative work right. 